\title{
Wabash River Integrated Methanol and Power Production from Clean Coal Technologies (IMPPCCT)
}

\author{
Quarterly Technical Progress Report No. 07
}

\author{
For the Period \\ April 1 - June 30, 2001 \\ Principal Authors: Doug Strickland \\ Albert Tsang \\ Report Date: February 7, 2003 \\ Prepared For \\ U.S. Department of Energy \\ Cooperative Agreement No. DE-FC26-99FT40659 \\ Gasification Engineering Corporation \\ 1000 Louisiana Street, Suite 3800 \\ Houston, Texas 77002 \\ and
}

Subcontractors: Air Products And Chemicals Inc., The Dow Chemical Company, Dow Corning Corporation, Methanex Corporation, And Siemens Westinghouse Power Corporation 


\section{DISCLAIMER}

This report was prepared by Gasification Engineering Corporation as an account of work pursuant to a cooperative agreement partially sponsored by an agency of the United Sates Department of Energy. Neither the Gasification Engineering Corporation, nor any of its subcontractors, nor the United States Department of Energy, nor any person or agency acting on behalf of either:

(A) Makes any warranty, express or implied, or assumes any legal liability or responsibility for the accuracy. Completeness, or usefulness of any information, apparatus, product or process disclosed, or represents that its use would not infringe privately owned rights.

(B) Assumes any liabilities with respect to the use of, or for damages resulting from the use of any information, apparatus, method or process disclosed in this report.

Reference herein to any specific commercial product, process, or service by trade name, trademark, manufacturer, or otherwise does not necessarily constitute or imply its endorsement, recommendation, or favoring by the United States Department of Energy nor any agency thereof. The views and opinions of authors expressed therein do not necessarily state or reflect those of the United States Department of Energy or any agency thereof. 


\section{ABSTRACT}

In a joint effort with the U.S. Department of Energy, working under a Cooperative Agreement Award from the "Early Entrance Coproduction Plant" (EECP) initiative, the Gasification Engineering Corporation and an Industrial Consortium are investigating the application of synthesis gas from the E-GAS ${ }^{\text {TM }}$ technology to a coproduction environment to enhance the efficiency and productivity of solid fuel gasification combined cycle power plants.

The objectives of this effort are to determine the feasibility of an Early Entrance Coproduction Plant located at a specific site which produces some combination of electric power (or heat), fuels, and/or chemicals from synthesis gas derived from coal, or, coal in combination with some other carbonaceous feedstock. The project's intended result is to provide the necessary technical, financial, and environmental information that will be needed to move the EECP forward to detailed design, construction, and operation by industry.

The Wabash River Integrated Methanol and Power Production from Clean Coal Technologies (IMPPCCT) project is evaluating integrated electrical power generation and methanol production through clean coal technologies. The project is conducted by a multi-industry team lead by Gasification Engineering Corporation (GEC), and supported by Air Products and Chemicals Inc., The Dow Chemical Company, Dow Corning Corporation, Methanex Corporation, and Siemens Westinghouse Power Corporation. Three project phases are planned for execution, including:

I. Feasibility Study and conceptual design for an integrated demonstration facility and for fence-line commercial plants operated at The Dow Chemical Company or Dow Corning Corporation chemical plant locations (i.e. the Commercial Embodiment Plant or CEP)

II. Research, development, and testing to address any technology gaps or critical design and integration issues 
III. Engineering design and financing plan to install an integrated commercial demonstration facility at the existing Wabash River Energy Ltd., plant in West Terre Haute, Indiana.

During the reporting period work was furthered to support the development of capital and operating cost estimates associated with the installation of liquid or gas phase methanol synthesis technology in a Commercial Embodiment Plant (CEP) utilizing the six cases previously defined. In addition, continued development of the plant economic model was accomplished by providing combined cycle performance data. Performance and emission estimates for gas turbine combined cycles was based on revised methanol purge gas information.

The economic model was used to evaluate project returns with various market conditions and plant configurations and was refined to correct earlier flaws. Updated power price projections were obtained and incorporated in the model.

Sensitivity studies show that break-even methanol prices which provide a $12 \%$ return are $47 \phi-54 \phi /$ gallon for plant scenarios using $\$ 1.25 / \mathrm{MM}$ Btu coal, and about $40 \phi /$ gallon for most of the scenarios with $\$ 0.50 / \mathrm{MM}$ Btu petroleum coke as the fuel source. One exception is a high power price and production case which could be economically attractive at $30 \phi / g a l l o n$ methanol. This case was explored in more detail, but includes power costs predicated on natural gas prices at the $95^{\text {th }}$ percentile of expected price distributions. In this case, the breakeven methanol price is highly sensitive to the required project return rate, payback period, and plant on-line time. These sensitivities result mainly from the high capital investment required for the CEP facility $(\sim 500 M M$ for a single train IGCC-methanol synthesis plant).

Finally, during the reporting period the Defense Contractor Audit Agency successfully executed an accounting audit of Global Energy Inc. for data accumulated over the first year of the IMPPCCT project under the Cooperative Agreement. 


\section{TABLE OF CONTENTS}

DISCLAIMER

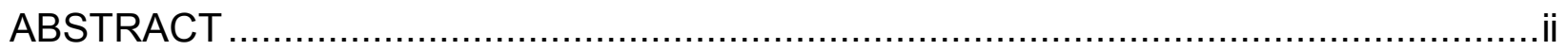

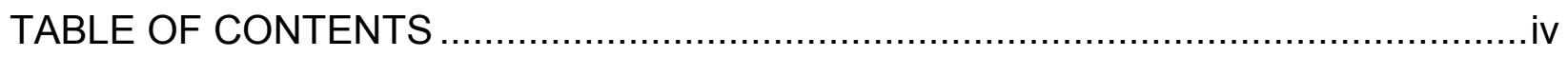

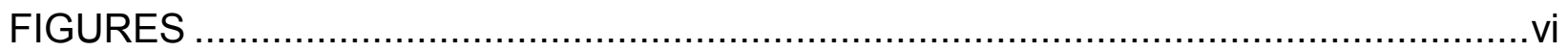

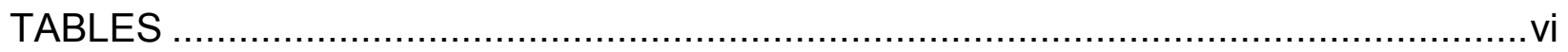

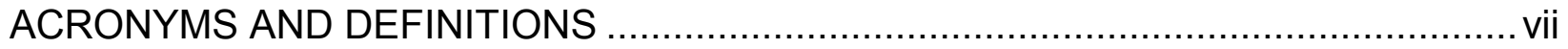

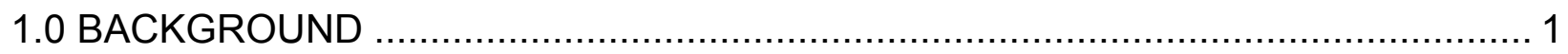

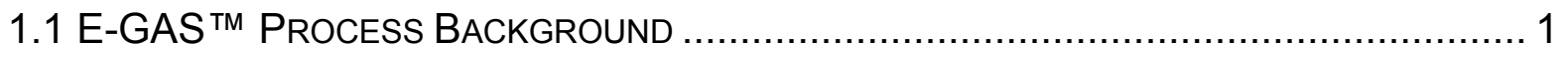

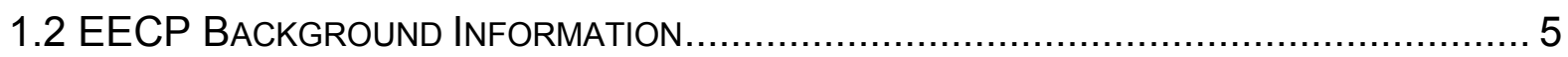

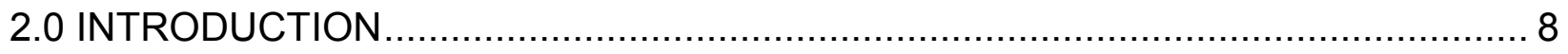

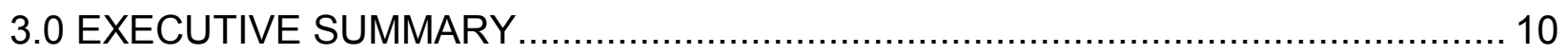

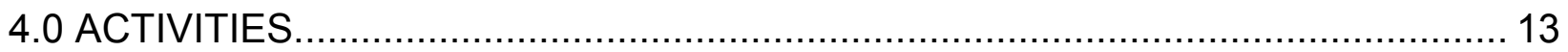

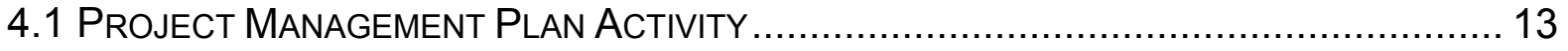

4.2 CEP ConcePt DeVELOPMENT ACtIVITY ................................................... 13

4.3 CeP Plant Performance \& Emission Estimation Activity.............................. 13

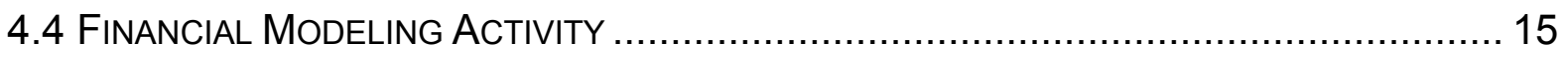

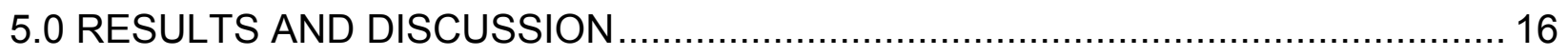

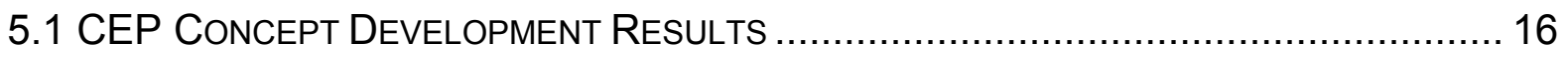

5.2 CeP Plant Performance and Emission Estimation Results ......................... 17

5.3.1 CEP FinANCIAL Modeling CASe StUdy ResultS....................................... 23

5.3.2 CEP Financial Modeling MaRket Sensitivity Study ResultS ...................... 27

5.3.3 CEP Financial Modeling Case-INTEgRation Sensitivity Study Results ...... 29

5.3.4 CEP Financial Modeling BReak-Even Sensitivity Study Results................ 31 
5.3.5 CeP financial Modeling Project Return Sensitivity Study Results ........ 35

5.3.6 CeP financial Modeling Plant Reliability Sensitivity Study Results........ 36

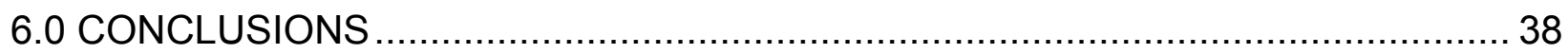

6.1 IGCC PeRformance And Emission Estimation Conclusions ........................... 39

6.2 CEP FinANCIAL Modeling StUdy CONCLUSIONS ......................................... 41

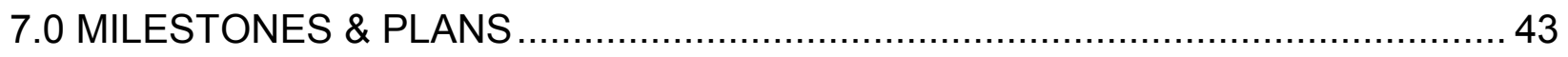

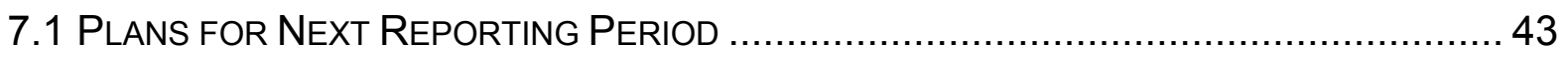

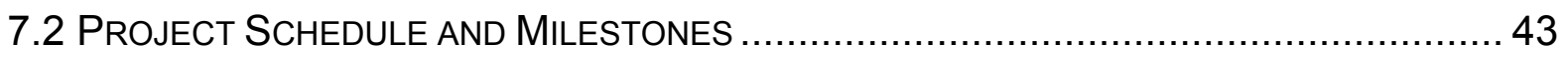

7.3 Project Cost - Plan And Actual ExpendituRe............................................. 45

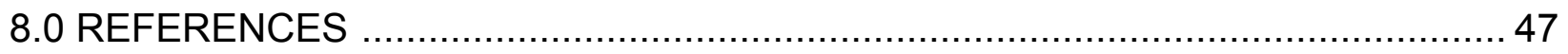

8.1 Selected References Available VIA the INTERnet ..................................... 47

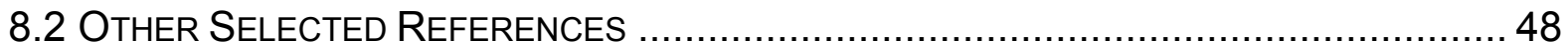




\section{FIGURES}

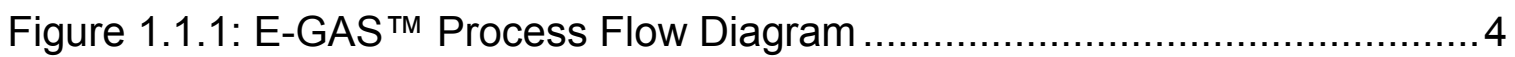

Figure 5.3.1.1: CEP Financial Model Scope \& Boundary Diagram ....................23

Figure 5.3.1.2: Financial model Scope for IGCC \& Methanol Plant Diagram .....24

Figure 5.3.2.1: CEP Electricity Price Projections (in 2001 dollars) ........................28

Figure 5.3.3.1: Financial Case Screening Results ......................................... 31

Figure 5.3.4.1: Breakeven Selling Price Screening Results............................ 32

Figure 5.3.4.2: Screening Results for Breakeven Methanol Price ....................34

Figure 5.3.4.3: Methanol Market Price Distribution Estimate ............................35

Figure 5.3.5.1: Break-Even Methanol \& Power Price; Return \& Payback

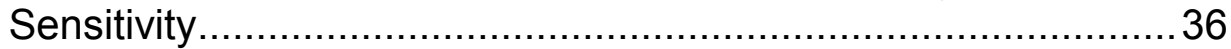

Figure 5.3.6.1: Break-Even Methanol Price; Plant Reliability Sensitivity.............37

Figure 7.2.1: IMPPCCT Phase I Milestones .................................................. 44

Figure 7.3.1 - Total Phase I Project Spending .............................................46

TABLES

Table 1.1.1: WREL Gasification Production Statistics during Clean Coal Program Demonstration Period ................................................................. 4

Table 1.1.2: Overall Thermal Performance of Gasification at WREL ..................5

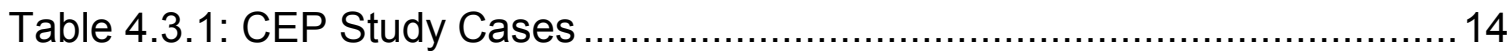

Table 5.2.1: Methanol Purge Gas Properties.............................................. 18

Table 5.2.2: Estimated CEP Combined Cycle Performance.............................20

Table 5.2.3: Estimated CEP Power Plant Effluent Stream Results ...................22

Table 5.3.1.1: Fenceline Plant CEP Case Studies .........................................27

Table 5.3.2.1: Feedstock and Product Prices Considered for Initial Sensitivity ..29

Table 5.3.4.1: Case Studies (with Fenceline Plant) Screening Results ..............33

Table 7.2.1: Phase I Deliverable Requirements by Task ................................45 
ACRONYMS AND DEFINITIONS

\begin{tabular}{|c|c|}
\hline Acronym & Description \\
\hline ASU & Air Separation Unit \\
\hline BFW & Boiler Feed-Water \\
\hline BGL & British Gas Lurgi \\
\hline CEP & Commercial Embodiment Plant \\
\hline ССТ & Clean Coal Technologies \\
\hline $\mathrm{CO}$ & Carbon Monoxide \\
\hline CT & Combustion Turbine \\
\hline DOE & Department of Energy \\
\hline EECP & Early Entrance Coproduction Plant \\
\hline E-GAS TM & Title of Global Energy, Inc.'s Gasification Process \\
\hline GEC & Gasification Engineering Corporation \\
\hline GJ & Giga Joule \\
\hline GPMEOH & Gas Phase Methanol \\
\hline $\mathrm{HHV}$ & Higher Heating Value \\
\hline HRSG & Heat Recovery Steam Generator \\
\hline HTHRU & High Temperature Heat Recovery Unit \\
\hline IGCC & Integrated Gasification Combined Cycle \\
\hline IMPPCCT & $\begin{array}{l}\text { Integrated Methanol and Power Production from Clean } \\
\text { Coal Technologies }\end{array}$ \\
\hline KPaa & Kilo Pascals Atmospheric (pressure) \\
\hline KPag & Kilo Pascals Gauge (pressure) \\
\hline LGTI & Louisiana Gasification Technology Incorporated \\
\hline
\end{tabular}




\begin{tabular}{|c|c|}
\hline Acronym & Description \\
\hline LOX & Liquid Oxygen \\
\hline LPMEOH $^{\mathrm{TM}}$ & Liquid Phase Methanol (process) \\
\hline MAC & Main Air Compressor \\
\hline MDEA & Methyl-Di-Ethanol Amine (solvent) \\
\hline MMBtu & Million British Thermal Units \\
\hline MP & Medium Pressure \\
\hline Mt & Metric Ton \\
\hline MTPD & Metric Ton Per Day \\
\hline MW & Mega Watt \\
\hline NETL & National Energy Testing Laboratory \\
\hline NOx & Oxides of Nitrogen (symbol) \\
\hline NPV & Net Present Value \\
\hline O\&M & Operating \& Maintenance \\
\hline PSE & Power Systems Engineering \\
\hline $\mathrm{RD} \& \mathrm{~T}$ & Research, Development \& Testing \\
\hline SFC & Synthetic Fuels Corporation \\
\hline $\mathrm{SRC}$ & Steam Raising Converter \\
\hline SWPC & Siemens Westinghouse Power Corporation \\
\hline Syngas & Synthesis Gas \\
\hline TPD & Tons Per Day \\
\hline WBS & Work Breakdown Structure (activities) \\
\hline WREL & Wabash River Energy Ltd. \\
\hline
\end{tabular}




\subsection{BACKGROUND}

\subsection{E-GAS ${ }^{\mathrm{TM}}$ Process Background}

The Gasification Engineering Corporation (GEC) headquartered in Houston Texas, develops and markets the E-GAS ${ }^{\mathrm{TM}}$ coal gasification process. The E-GAS ${ }^{\mathrm{TM}}$ technology is utilized at the Wabash River Energy Ltd. (WREL) facility, which is located at Cinergy Energy's Wabash River Generating Station in West Terre Haute, Indiana. GEC and WREL are wholly owned subsidiaries of Global Energy Inc. headquartered in Cincinnati, Ohio.

The E-GAS ${ }^{\mathrm{TM}}$ process features an oxygen-blown, continuous-slagging, two-stage, entrained-flow gasifier, which uses natural gas for start-up. Coal or petroleum coke is milled with water in a rod-mill to form slurry. The slurry is combined with oxygen in mixer nozzles and injected into the first stage of the gasifier, which operates at $2600^{\circ} \mathrm{F}$ and $400 \mathrm{psi}$. A turnkey, Air Liquide, 2,060-ton/day low-pressure cryogenic distillation facility that WREL owns and operates, supplies oxygen of $95 \%$ purity.

In the first stage, slurry fuel undergoes a partial oxidation reaction at temperatures high enough to bring the coal's ash above its melting point. The fluid ash falls through a taphole at the bottom of the first stage into a water quench, forming an inert vitreous slag. The synthesis gas produced by this reaction then flows to the second stage, where additional coal slurry is injected. This coal is pyrolyzed in an endothermic reaction with the hot synthesis gas to enhance the heating value of the synthesis gas and to improve overall efficiency of the process.

The synthesis gas then flows to the high-temperature heat-recovery unit (HTHRU), essentially a fire-tube steam generator, to produce high-pressure saturated steam. After cooling in the HTHRU, particulates in the synthesis gas called char are removed in a hot/dry filter and recycled to the gasifier where the carbon content in the char is converted into synthesis gas. The synthesis gas is further cooled in a series of heat exchangers, is water scrubbed for chloride removal, and is passed through a catalyst, which hydrolyzes carbonyl sulfide into hydrogen sulfide. Hydrogen sulfide is removed 
from the synthesis gas using a methyl-di-ethanol-based amine solvent in an absorber/stripper column process. The "sweet" synthesis gas is then moisturized, preheated, and piped over to the power block.

The key elements of the power block are the General Electric MS 7001 FA (GE 7 FA) high-temperature combustion turbine/generator, the heat recovery steam generator (HRSG), and the repowered steam turbine. The GE 7 FA is a dual-fuel turbine (synthesis gas for operations and No. 2 fuel oil for startup) that is capable of generating a nominal $192 \mathrm{MW}$ when firing synthesis gas, about seven percent $(7 \%)$ higher power production than the same turbine fired on natural gas. The enhanced power production is attributed to the increased mass flows associated with synthesis gas. Steam injection is used for control of nitrogen oxides called NOx within the combustion turbine. The required steam flow is minimal compared to that of conventional systems as the synthesis gas is moisturized at the gasification facility, by recovery of low-level heat in the process. The water consumed in this process is continuously made up at the power block by water treatment systems, which clarify and further treat river water.

The HRSG for this project is a single-drum design capable of superheating 754,000 $\mathrm{lb} / \mathrm{hr}$ of high-pressure steam at $1010^{\circ} \mathrm{F}$, and $600,820 \mathrm{lb} / \mathrm{hr}$ of reheat steam at $1010^{\circ} \mathrm{F}$ when operating on design-basis synthesis gas. The HRSG configuration was specifically optimized to utilize both the gas-turbine exhaust energy and the heat energy made available in the gasification process. The nature of the gasification process in combination with the need for strict temperature and pressure control of the steam turbine led to a great deal of creative integration between the HRSG and the gasification facility. The repowered steam turbine produces $104 \mathrm{MW}$, which combines with the combustion turbine generator's $192 \mathrm{MW}$ and the system's auxiliary load of approximately $34 \mathrm{MW}$ to yield $262 \mathrm{MW}$ (net) to the Cinergy grid.

The Air Separation Unit (ASU) provides oxygen and nitrogen for use in the gasification process but is not an integral part of the plant thermal balance. The ASU uses services 
such as cooling water and steam from the gasification facilities and is operated from the gasification plant control room.

The gasification facility produces two commercial by-products during operation. Sulfur, which is ultimately removed as 99.99 percent pure elemental sulfur, is marketed to sulfur users. Slag is targeted as an aggregate in asphalt roads and as structural fill in various types of construction applications. In fact, the roads at the WREL facility have been top-coated with asphalt incorporating slag as the aggregate. Furthermore, at least two surrounding area sites have been audited, approved, and have used WREL generated slag as structural fill under the Solid Waste Management Rules of Indiana. Another beneficial use of the slag by-product is as a fluxing agent during petroleum coke operation as this feed is typically deficient in mineral content required for proper slag fusion and flow. For this use, WREL has retained a reserve supply of slag generated from coal gasification.

The E-GAS ${ }^{\mathrm{TM}}$ process flow diagram presented as Figure 1.1.1 illustrates the features and components described in the above text. In Table 1.1.1 the WREL production statistics are presented by year in both English and Metric units. In Table 1.1.2 the WREL thermal performance variables are compared to the process design basis for both coal and petroleum coke feedstocks.

For additional information on the Wabash Plant, please refer to Reference 8.1. 
Figure 1.1.1: E-GAS ${ }^{\mathrm{TM}}$ Process Flow Diagram

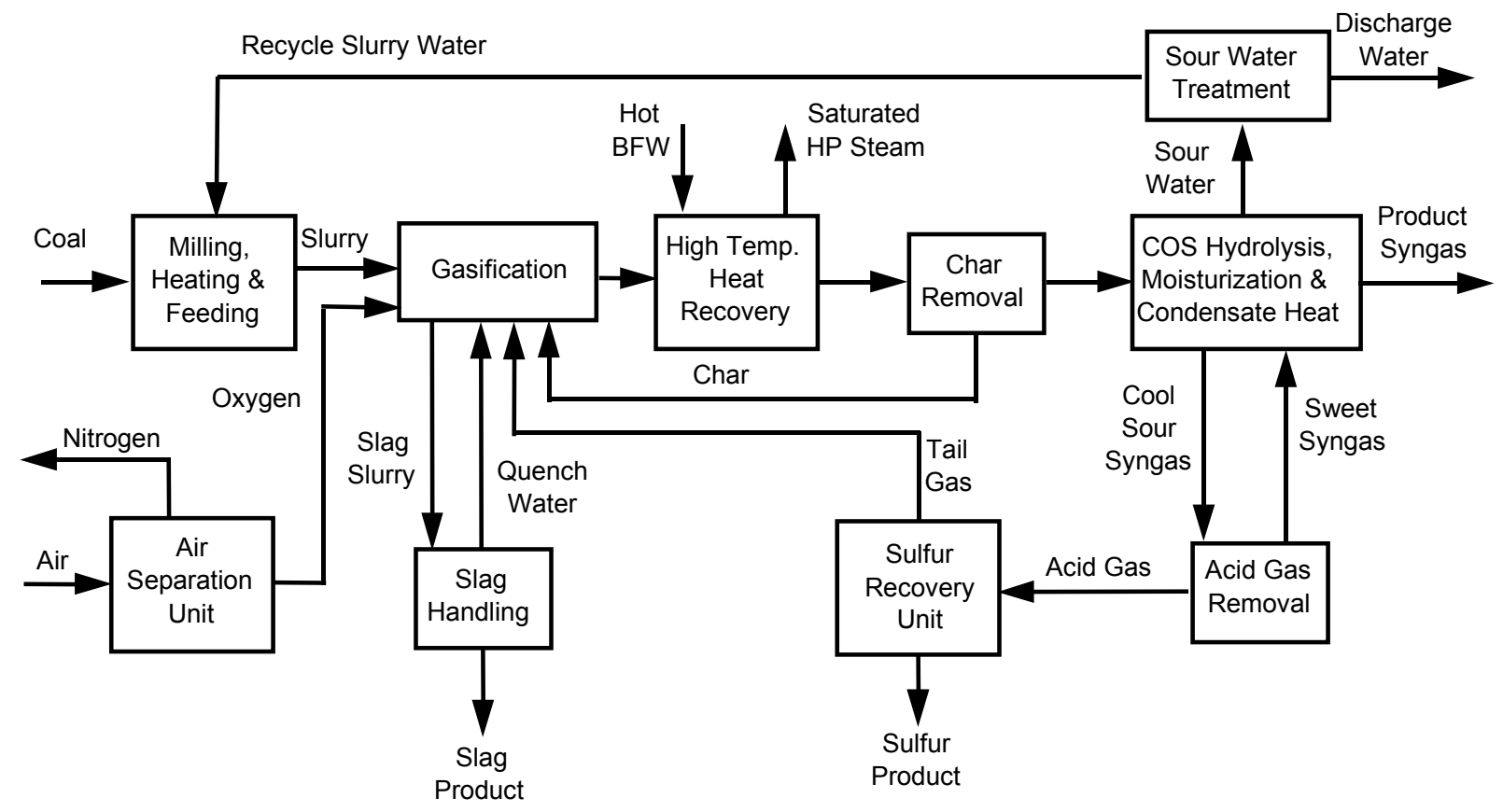

Table 1.1.1: WREL Gasification Production Statistics during Clean Coal Program Demonstration Period

\begin{tabular}{|c|c|c|c|c|c|}
\hline \multirow{2}{*}{ Production Variable } & \multicolumn{5}{|c|}{ Production Year } \\
\cline { 2 - 6 } & 1996 & 1997 & 1998 & 1999 & 2000 \\
\hline Gasifier Operation, Hrs & 1,902 & 3,885 & 5,279 & $3,496^{*}$ & $3,406^{* *}$ \\
\hline $\begin{array}{c}\text { Dry Synthesis Gas } \\
\text { Produced, GJ (MMBtu) }\end{array}$ & $\begin{array}{c}2,922,015 \\
(2,769,683)\end{array}$ & $\begin{array}{c}6,555,626 \\
(6,213,864)\end{array}$ & $\begin{array}{c}9,316,716 \\
(8,831,011)\end{array}$ & $\begin{array}{c}6,132,874 \\
(5,813,151)\end{array}$ & $\begin{array}{c}5,497,588 \\
(5,210,984)\end{array}$ \\
\hline $\begin{array}{c}\text { Coal Processed, Mt } \\
\text { (Short Tons) }\end{array}$ & $\begin{array}{c}167,270 \\
(184,381)\end{array}$ & $\begin{array}{c}356,368 \\
(392,822)\end{array}$ & $\begin{array}{c}500,316 \\
(551,495)\end{array}$ & $\begin{array}{c}335,538 \\
(369,862)\end{array}$ & $\begin{array}{c}290,034 \\
(319,703)\end{array}$ \\
\hline $\begin{array}{c}\text { Longest Operating } \\
\text { Campaign, (days) }\end{array}$ & 19 & 46 & 82 & 60 & 104 \\
\hline
\end{tabular}

* Three months of production were lost to the GE 7FA compressor failure \& repair.

** Three months of production were lost during commercial negotiations required when the WREL facility transitioned to market-based operation. 
Table 1.1.2: Overall Thermal Performance of Gasification at WREL

\begin{tabular}{|c|c|c|c|}
\hline \multirow{2}{*}{ Performance Feature } & \multirow{2}{*}{ Design } & \multicolumn{2}{|c|}{ Actual Performance } \\
\cline { 3 - 4 } & & Coal & Coke \\
\hline Nominal Throughput, TPD & 2550 & 2450 & 2000 \\
\hline Synthesis gas Capacity, MMBtu/hr & 1780 & $1690^{\dagger}$ & $1690^{\dagger}$ \\
\hline Combustion Turbine, MW & 192 & 192 & 192 \\
\hline Steam Turbine, MW & 105 & 96 & 96 \\
\hline Aux. Power, MW & 35 & 36 & 36 \\
\hline Net Generation, MW & 262 & 261 & 261 \\
\hline Plant Efficiency, \% (HHV) & 37.8 & 39.7 & 40.2 \\
\hline Sulfur Removal Efficiency, \% & $>98$ & $>99$ & $>99$ \\
\hline
\end{tabular}

t Synthesis gas capacity referenced for coal and petroleum coke are the actual quantities fed to the combustion turbine when $192 \mathrm{MW}(100 \%)$ of power generation occurs.

\subsection{EECP Background Information}

The request for Cooperative Agreement Proposals under the "Early Entrance Coproduction Plant (EECP)," Solicitation Number DE-SC26-99FT40040 was issued on February 17, 1999, by the United States Department of Energy.

The objective of this effort is to determine the feasibility of an EECP located at a specific site which produces some combination of electric power (or heat), fuels, and/or chemicals from synthesis gas derived from coal, or, coal in combination with some other carbonaceous feedstock. The scope of this effort includes:

a. Market analysis to define site-specific product requirements (i.e. products needed by market, market size, and price), process economics, feedstock availability and feedstock cost; 
b. System analysis to define feedstocks, feedstock preparation, conversion to synthesis gas, synthesis gas cleanup, and conversion of synthesis gas to market-identified products;

c. Preliminary engineering design of the EECP facility;

d. Preparation of a Research, Development, and Testing (RD\&T) plan that addresses the technical uncertainties associated with eventual design, construction, and operation of the EECP;

e. Implementation of RD\&T Plan;

f. Revision of the preliminary engineering design; and

g. Preparation of a project financing prospectus for obtaining private sector funding to perform the detailed design, construction, and operation of the EECP.

Efforts under Solicitation No. DE-SC26-99FT40040, must support an EECP that at a minimum:

1. Is a single-train facility of sufficient size to permit scaling to commercial size with minimal technical risk;

2. Provides the capability of processing multiple feedstocks (must be capable of processing coal) and producing more than one product;

3. Is undertaken by an industrial consortium;

4. Reduces risk such that future coproduction plants may be deployed with no government assistance; and

5. Meets or exceeds environmental requirements and discusses the issue of carbon dioxide reduction by one or more routes, which include mitigation, utilization, and sequestration.

Using a focused RD\&T Plan, the EECP project will enhance the development and commercial acceptance of coproduction technology that produces high-value products, particularly those that are critical to our domestic chemical, fuel, and power requirements. The proposed project will resolve critical knowledge and technology gaps on the integration of gasification and downstream processing to coproduce some combination of power, fuels and/or chemicals from coal and other carbonaceous 
feedstocks. The project's intended result is to provide the necessary technical, economic, and environmental information that will be needed to move the EECP forward to detailed design, construction, and operation by industry. 


\subsection{INTRODUCTION}

The Wabash River Integrated Methanol and Power Production from Clean Coal Technologies (IMPPCCT) project is a $\$ 4.92$ million cooperative agreement between the United States Department of Energy (DOE) and the Gasification Engineering Corporation (GEC) to evaluate the integration of gasification-based electrical generation and methanol production processes to determine the economic and technical feasibility of power/chemicals coproduction. A multi-industry team led by GEC and consisting of Air Products \& Chemicals, Inc., Dow Chemical Company, Dow Corning Corporation, Methanex Corporation, and Siemens Westinghouse Power Corporation will perform the IMPPCCT study.

The consortium for the Wabash River IMPPCCT plans to analyze and develop a concept of methanol and power production based on GEC's E-GAS ${ }^{\text {TM }}$ Gasification Process utilizing coal and other feedstocks. In a planned three-Phase project, this team plans to review and fully analyze the domestic methanol market, examine the criteria needed and develop a robust financial model to study the economics of fullscale implementation of this gasification to power and methanol coproduction concept. Potential Dow Chemical and Dow Corning sites for the Commercial Embodiment Plant (CEP) will be examined. Feasibility studies, testing and engineering, and financing of IMPPCCT based on addition of methanol production facilities at the Wabash River Energy Limited (WREL) Gasification Plant in West Terre Haute, Indiana will be developed to enable the commercialization of the gasification-methanol production concept.

The vision of this project is to demonstrate the commercial viability of producing electric power, process energy (steam), and chemicals (methanol) from coal and other hydrocarbon feedstocks to satisfy the demands of at least two types and corresponding sizes of host chemical complexes. An efficient, low capital, integrated facility will convert the feedstock initially to synthesis gas and ultimately to electric power, process energy, and methanol with a series of reliable, commercially proven, and environmentally sound unit operations. The chemical products, required process 
energy, and at least a portion of the electric power will be delivered to the host chemical complex for further conversion to higher value products. Any products in excess of the requirements of the host chemical complex will be sold through readily accessible distribution networks. The CEP will be technically verified from the IMPPCCT demonstration in Phase II and commercially verified by an economic model and a project financing prospectus. 


\subsection{EXECUTIVE SUMMARY}

The Wabash River Energy Limited (WREL) facility is a project selected and co-funded under Round IV of the U.S. Department of Energy's Clean Coal Technology Program. In this project, coal and/or other solid fuel feedstocks are gasified in an oxygen-blown, entrained-flow gasifier with continuous slag removal and a dry particulate removal system. The resulting product synthesis gas is used to fuel a combustion turbine generator whose exhaust is integrated with a heat recovery steam generator to drive a refurbished steam turbine generator. The gasifier uses technology initially developed by The Dow Chemical Company (the Destec Gasification Process), and now offered commercially by Global Energy, Inc., as the E-GAS TM technology.

The project demonstration was completed in December 1999, having achieved all of its objectives. The facility built for this project is located at Cinergy Corporation's Wabash River Generating Station near West Terre Haute, Indiana.

The WREL project successfully demonstrated commercial application of the E-GAS ${ }^{\mathrm{TM}}$ coal gasification technology in conjunction with power generation. Operating time exceeds 18,000 hours, with over 5 million MWH of power produced. The combustion turbine generates $192 \mathrm{MW}$ and the repowered steam turbine generates $104 \mathrm{MW}$. With the system's parasitic load of $34 \mathrm{MW}$, net power production is $262 \mathrm{MW}$, which meets the target goal. The plant operates successfully on baseload dispatch in the Cinergy power grid, and continues to operate as a privately owned facility providing power to Cinergy.

Gasification is an environmentally superior means of utilizing domestic coal resources for power production. It also offers the opportunity to use lower quality, less expensive feedstocks such as petroleum coke. Petroleum coke operation was tested and has been commercially demonstrated at the WREL facility since August of 2000 , resulting in over 3300 hours of operational experience. 
Sulfur removal from the gasifier's solid feed is recovered and sold, as is the slag byproduct. Sulfur removal exceeds $97 \%$, resulting in $\mathrm{SO}_{\mathrm{X}}$ emissions of $0.1 \mathrm{lb} / \mathrm{million}$ Btu, which is far below regulatory requirements of $1.2 \mathrm{lb} /$ million Btu. Particulate emissions are less than the detectible limit and NOx emissions are $0.15 \mathrm{lb} / \mathrm{million} \mathrm{Btu}$, which meets the current target for coal-fired power generation plants. The WREL facility is the cleanest commercial scale solid fuel-based power plants in the world.

In a joint effort with the U.S. Department of Energy (DOE), a Cooperative Agreement titled "Integrated Methanol and Power Production from Clean Coal Technologies" (IMPPCCT), was awarded under the Early Entrance Coproduction Plant (EECP) solicitation to Gasification Engineering Corporation (GEC), a Global Energy company. An Industrial Consortium led by GEC is investigating the use of synthesis gas produced by the E-GAS ${ }^{\mathrm{TM}}$ technology in a coproduction environment to enhance the efficiency and productivity of solid fuel gasification combined cycle plants.

The objectives of this effort are to determine the feasibility of an EECP located at a specific site which produces some combination of electric power (or heat), fuels, and/or chemicals from synthesis gas derived from coal, or, coal in combination with some other carbonaceous feedstock. The project's intended result is to provide the necessary technical, economic, and environmental information that will be needed to move the EECP forward to detailed design, construction, and operation by industry.

During the reporting period work was furthered to support the development of capital and operating cost estimates associated with the installation of liquid and gas phase methanol synthesis technology in a Commercial Embodiment Plant (CEP). In addition, continued development of the plant economic model was accomplished through the generation of combined cycle performance data. Performance and emission estimates for gas turbine combined cycles were based on revised methanol purge gas information submitted by the Consortium for their relative areas of expertise. 
The economic model was used to evaluate project returns with various market conditions and plant configurations and was refined to correct earlier flaws. Updated power price projections were obtained and incorporated in the model.

Sensitivity studies show that break-even methanol prices which provide a $12 \%$ return are $47 \phi-54 \phi /$ gallon for plant scenarios using $\$ 1.25 / \mathrm{MM}$ Btu coal and about $40 \phi /$ gallon for most of the scenarios with $\$ 0.50 / \mathrm{MM}$ Btu petroleum coke as the fuel source. One exception is a high power price and production case which could be economically attractive at $30 \% / g a l l o n$ methanol. This case was explored in more detail, but includes power costs predicated on natural gas prices at the $95^{\text {th }}$ percentile of expected price distributions. In this case, the breakeven methanol price is highly sensitive to the required project return rate, payback period and plant on-line time. These sensitivities result mainly from the high capital investment required for the CEP facility $(\sim 500 \mathrm{MM}$ for a single train IGCC-methanol synthesis plant).

Also during the reporting period the Defense Contractor Audit Agency successfully executed an accounting audit of Global Energy Inc. for data accumulated over the first year of the IMPPCCT project under the Cooperative Agreement.

Actual expenditure for the reporting period was $\$ 52,902$, with cumulative actual expenditure for the project to be $\$ 661,354$. The figures include funding from DOE, which is at $80 \%$ of the total, and cost share provided by the consortium members. Total budget for the project is $\$ 1,933,628$, with DOE providing $\$ 1,546,902$. 


\subsection{ACTIVITIES}

\subsection{Project Management Plan Activity}

The Defense Contractor's Auditing Agency successfully executed an accounting audit of Global Energy Inc. for data accumulated over the first year of the IMPPCCT project under the Cooperative Agreement. Results and conclusions related to the execution of this study have not been submitted to Global Energy Inc. during the reporting period.

\subsection{CEP Concept Development Activity}

Gasification Engineering Corporation (GEC) provided a consolidated spreadsheet containing the Commercial Embodiment Plant (CEP) cases planned for further development and study to the team for intended use by Dow Corning to finalize input to the financial model. All team members were requested to complete the spreadsheet for their areas of expertise. The information requested had been supplied by the team throughout the reporting period, however, it had not been consolidated into a useful document.

Later in the reporting period, Dow Corning provided the preliminary conclusions derived from the model for group discussion. Once again, all team participants generated scenarios to test the model and submitted them for analysis by Dow Corning. Coincident to the test scenarios, the consortium members were also asked to verify information already used as input to the model.

\subsection{CEP Plant Performance \& Emission Estimation Activity}

The CEP can be designed to convert either coal or petroleum coke into methanol and power. In an attempt to define the range of mixtures of methanol and power, two sets of cases were selected to represent extreme designs: low conversion (LC) cases and high conversion $(\mathrm{HC})$ cases. Either petroleum coke or coal can fuel both sets of cases, and the $\mathrm{HC}$ cases can use either the liquid phase or gas phase (GPMEOH) methanol synthesis process. The six resulting cases are identified in Table 4.3.1. The financial modeling team utilizes an additional case " 0 " as a baseline case intended for use as a comparison benchmark. This case is presented in more detail in section 5.4. 
Table 4.3.1: CEP Study Cases

\begin{tabular}{|c|c|c|c|}
\hline Case \# & Coproduction Mode & MEOH Process & Feedstock \\
\hline 1 & Low methanol / High Power & Liquid Phase & Petroleum Coke \\
\hline 2 & Low methanol / High Power & Liquid Phase & Coal \\
\hline 3 & High methanol / Low Power & Liquid Phase & Petroleum Coke \\
\hline 4 & High methanol / Low Power & Liquid Phase & Coal \\
\hline 5 & High methanol / Low Power & Gas Phase & Petroleum Coke \\
\hline 6 & High methanol / Low Power & Gas Phase & Coal \\
\hline
\end{tabular}

The LC cases are appropriate for commercial sites where power, steam, and methanol are useful products, but power is desired at higher thermal conversion quantities (Btu basis) compared to methanol. The LC cases utilize E-GAS ${ }^{\mathrm{TM}}$ gasification technology provided by GEC and the Liquid Phase Methanol Process (LPMEOH ${ }^{\mathrm{TM}}$ ) process provided by Air Products for chemical production. Purge gas from the LPMEOH ${ }^{\mathrm{TM}}$ unit is directed to the gas turbine combined cycle for power production.

The $\mathrm{HC}$ cases are appropriate for use at commercial sites where power is not as important as steam and methanol production, defining the highest envelope of methanol synthesis expected from the commercial embodiment design options. The $\mathrm{HC}$ cases utilize the same E-GAS ${ }^{\mathrm{TM}}$ gasification technology, but methanol synthesis may be either the LPMEOH ${ }^{\mathrm{TM}}$ process from Air Products or conventional GPMEOH process from Methanex Corporation. Conversion efficiency is anticipated to be similar for both methanol synthesis processes since both require balanced synthesis gas to achieve maximum methanol production. The purge gas streams in the $\mathrm{HC}$ cases are small compared to those in the LC cases, but are still intended for power production. Methanol purge gas compositions for the six CEP cases are based on data submitted from the consortium. 


\subsection{Financial Modeling Activity}

The economic model developed for evaluating the Integrated Gasification Combined Cycle (IGCC) and methanol facility was refined. The basic outline of the Commercial Embodiment Plant (CEP) model's scope did not change from earlier work. The model includes feedstocks of petroleum coke or coal to the IGCC and methanol production unit.

This block produces power and methanol and has synthesis gas, nitrogen, and steam as auxiliary products, which can be used by a methanol-based chemical manufacturing plant located at the fenceline. Excess power can be sold to external markets. Because the IGCC and methanol units are about $80 \%$ reliable, makeup sources are required to keep the fenceline plant operational while repairs and maintenance are completed. 


\subsection{RESULTS AND DISCUSSION}

The consortium for the WREL IMPPCCT project, led by GEC, and including Dow Corning, Dow Chemical, Air Products, Methanex, and Siemens Westinghouse, continued to analyze and develop a concept of methanol and power production based on GEC's E-GAS ${ }^{\mathrm{TM}}$ Gasification Process utilizing coal and petroleum coke feedstocks. Feasibility studies, testing and engineering, and financing of an integrated methanol and electric power coproduction facility using clean coal technologies based on the addition of methanol production facilities at the WREL gasification plant in West Terre Haute, Indiana, will be developed to enable the commercialization of the gasification to methanol and power coproduction concept.

\subsection{CEP Concept Development Results}

During the reporting period GEC provided a consolidated spreadsheet containing the CEP cases planned for further development and study to the team for use by Dow Corning to finalize input to the financial model. All team members were requested to complete the spreadsheet for their areas of expertise. The information requested was supplied by the team throughout the reporting period, however, it had not been consolidated into a useful document and was therefore submitted directly to Dow Corning for use as needed within the model.

Later in the reporting period, Dow Corning provided the preliminary conclusions derived from the model for group discussion. All team participants in the consortium generated scenarios to test the model and submitted them for analysis by Dow Corning. Coincident to the test scenarios, the consortium members were also asked to verify information already used as input to the model. 


\subsection{CEP Plant Performance and Emission Estimation Results}

Using clean coal technologies, the CEP can be designed to convert either coal or petroleum coke into methanol and power for integrated methanol and power coproduction. In an attempt to define the range of mixtures of methanol and power, two sets of cases were selected to represent extreme designs: low conversion (LC) cases and high conversion $(\mathrm{HC})$ cases. Either petroleum coke or coal can fuel both sets of cases, and the $\mathrm{HC}$ cases can use either the liquid phase ( $\mathrm{LPMEOH}^{\mathrm{TM}}$ ) or conventional gas phase (GPMEOH) methanol synthesis process. The six resulting cases are identified in Table 4.3.1.

Within the consortium, Air Products generated the performance data and capital and operating costs for the methanol production units identified in CEP Cases 1 through 4. Methanex provided the performance data and operating and capital costs for the methanol production units in Cases 5 and 6 . Methanex also delivered performance data and capital and operating costs for the equipment required to shift carbon monoxide in the synthesis gas to carbon dioxide, a process requirement common to Cases 3 through 6. Air Products completed performance data and capital and operating costs on carbon dioxide removal from the synthesis gas also required for Cases 3 through 6 .

The LC cases are appropriate for commercial sites where power, steam, and methanol are useful products, but power is desired at higher thermal conversion quantities (heating value basis) compared to methanol. Purge gas from the LPMEOH ${ }^{\mathrm{TM}}$ unit is directed to the gas turbine combined cycle for power production.

The $\mathrm{HC}$ cases are appropriate for use at commercial sites where power is not as important as steam and methanol production. These cases define the highest envelope of methanol synthesis expected from the commercial embodiment design options. 
Conversion efficiency is anticipated to be similar for both liquid and gas phase candidate processes since they both require balanced synthesis gas to achieve maximum methanol production. The purge gas streams in the $\mathrm{HC}$ cases are small compared to those in the LC cases, but are still intended for power production. Table 5.2.1 shows the methanol purge gas compositions for the six CEP cases, based on the data generated and supplied by the consortium members.

Table 5.2.1: Methanol Purge Gas Properties

\begin{tabular}{|c|c|c|c|c|c|c|}
\hline Case Number & 1 & 2 & 3 & 4 & 5 & 6 \\
\hline Solid Fuel Type & Petcoke & Coal & Petcoke & Coal & Petcoke & Coal \\
\hline Conversion Case & Low & Low & High & High & High & High \\
\hline MEOH Process & LPMEOH $^{\mathrm{TM}}$ & LPMEOH $^{\mathrm{TM}}$ & LPMEOH $^{\mathrm{TM}}$ & LPMEOH $^{\mathrm{TM}}$ & GPMEOH & GPMEOH \\
\hline Composition (vol\%) & & & & & & \\
\hline $\mathrm{CH}_{3} \mathrm{OH}$ & 0.0 & 0.0 & 0.0 & 0.0 & 0.3 & 0.4 \\
\hline $\mathrm{H}_{2}$ & 11.9 & 15.7 & 63.0 & 63.0 & 33.1 & 36.9 \\
\hline $\mathrm{CO}$ & 79.0 & 74.0 & 3.0 & 3.0 & 3.2 & 2.9 \\
\hline $\mathrm{N}_{2}$ & 1.6 & 2.4 & 16.0 & 16.0 & 37.2 & 39.5 \\
\hline $\mathrm{CO}_{2}$ & 2.8 & 2.7 & 9.5 & 9.5 & 6.4 & 6.7 \\
\hline $\mathrm{H}_{2} \mathrm{O}$ & 0.0 & 0.0 & 0.0 & 0.0 & 0.0 & 0.0 \\
\hline $\mathrm{CH}_{4}$ & 1.9 & 1.7 & 8.0 & 8.0 & 19.8 & 13.5 \\
\hline $\mathrm{H}_{2} \mathrm{~S}$ & 0.0 & 0.0 & 0.0 & 0.0 & 0.0 & 0.0 \\
\hline COS & 0.0 & 0.0 & 0.0 & 0.0 & 0.0 & 0.0 \\
\hline $\mathrm{NH}_{3}$ & 0.0 & 0.0 & 0.0 & 0.0 & 0.0 & 0.0 \\
\hline $\mathrm{Ar}$ & 2.0 & 2.5 & 0.0 & 0.0 & 0.0 & 0.0 \\
\hline $\mathrm{O}_{2}$ & 0.0 & 0.0 & 0.00 & 0.0 & 0.0 & 0.0 \\
\hline Total & 99.2 & 99.0 & 99.5 & 99.5 & 100.0 & 99.9 \\
\hline LHV, (Btu/scf) & 303.1 & 295.7 & 254.9 & 254.9 & 283.1 & 236.0 \\
\hline
\end{tabular}

The low-conversion cases (Cases 1 and 2) generate enough purge gas to fuel large industrial gas turbine combined cycles, but the high-conversion cases $(3,4,5$, and 6$)$ produce much less purge gas. For Cases 3 and 4, candidate power systems were selected from a list of smaller commercial combined cycles that use between 17 and $150 \mathrm{MWt}$ (60 to $500 \mathrm{MBtu} / \mathrm{hr}$ ) of fuel input. The Rolls Royce RB11 combined cycle selected for high-conversion Cases 3 and 4 was the only $60-\mathrm{Hz}$ machine with fuel requirements within $20 \%$ of the thermal input. Economic evaluations indicate that the 
purge gas streams in Cases 5 and 6 are not suited to a combined cycle, so the estimates for these cases are for package boilers with $20 \%$ excess air.

The preliminary combined cycle performance estimates in Table 5.2.2 are provided as an indication of the level of performance that might be expected. Net power outputs are for the combined cycle only, without deductions for air separation unit (ASU) or other plant auxiliary power requirements. None of the values provided imply any guarantees or warranted contractual commitments to actual future gas turbine performance. 
Table 5.2.2: Estimated CEP Combined Cycle Performance

\begin{tabular}{|c|c|c|c|c|c|c|}
\hline Case Number & 1 & 2 & 3 & 4 & 5 & 6 \\
\hline Solid Fuel Type & Petcoke & Coal & Petcoke & Coal & Petcoke & Coal \\
\hline Conversion Case & Low & Low & Hiah & High & High & Hiah \\
\hline MEOH Process & $\mathrm{LPMEOH}^{\mathrm{TM}}$ & LPMEOH $^{\mathrm{TM}}$ & LPMEOH $^{\mathrm{TM}}$ & LPMEOH $^{\mathrm{TM}}$ & GPMEOH & GPMEOH \\
\hline \multicolumn{7}{|l|}{ Methanol Purge Gas } \\
\hline $\begin{array}{l}\text { Available purge gas, } \\
\text { KBtu/hr }\end{array}$ & 1,688 & 1,365 & 325 & 325 & 150 & 171 \\
\hline $\begin{array}{l}\text { Available purge gas, } \\
\text { MW(t) }\end{array}$ & 495 & 400 & 103 & 103 & 44 & 50 \\
\hline \multicolumn{7}{|l|}{ Moist Syngas [1] } \\
\hline LHV, Btu/scf & 227.4 & 221.8 & 191.2 & 191.2 & 212.3 & 177.0 \\
\hline $\begin{array}{l}\text { Available moist } \\
\text { synthesis gas, } \mathrm{lb} / \mathrm{s}\end{array}$ & 127.0 & 102.0 & 16.8 & 16.8 & 9.3 & 12.7 \\
\hline $\begin{array}{l}\text { Moist synthesis gas } \\
\text { used, lb/s }\end{array}$ & 91.8 & 91.0 & 14.1 & 14.1 & 9.3 & 12.7 \\
\hline $\begin{array}{l}\text { Moist synthesis gas } \\
\text { used / available, Ib/s }\end{array}$ & $72 \%$ & $89 \%$ & $84 \%$ & $84 \%$ & $100 \%$ & $100 \%$ \\
\hline \multicolumn{7}{|l|}{ Power Generation [2] } \\
\hline Gas turbine model & W501D5 & W501D5 & RB211 & RB211 & $\mathrm{N} / \mathrm{a}$ & $\mathrm{N} / \mathrm{a}$ \\
\hline $\begin{array}{l}\text { Gas turbine power, } \\
\text { MW }\end{array}$ & 133.6 & 133.6 & 31.2 & 31.2 & 0 & 0 \\
\hline $\begin{array}{l}\text { Steam turbine power, } \\
\text { MW }[3]\end{array}$ & 61.1 & 64.9 & 9.5 & 9.5 & 0 & 0 \\
\hline Gross power, MW [3] & 194.7 & 198.5 & 40.7 & 40.7 & 0 & 0 \\
\hline
\end{tabular}

[1] Water or steam is added to the purge gas so that the resulting moist purge gas contains $25 \%(\mathrm{vol}) \mathrm{H}_{2} \mathrm{O}$.

[2] The gas turbine information provided is an indication of the level of performance that might be expected. None of the values provided imply any guarantees or warranted contractual commitments to actual future gas turbine performance.

[3] Performance estimates are for $60-\mathrm{Hz}$ gas turbine combined cycles operating on moist purge gas. Syngas feed pressures are 75-psi above GT burner pressures. Gas turbine combustion systems are assumed to control NOx by steam injection, using a ratio of $0.3 \mathrm{lb}\left(\mathrm{H}_{2} \mathrm{O}\right) / \mathrm{lb}$ (synthesis gas). Steam turbine performance assumes gasifier-steam interaction; additional interactions would change steam turbine performance. Gross power does not include ASU or plant auxiliaries.

These performance estimates are based on simplified plant designs that include only general site conditions, process flow diagrams, and capacities. The uncertainty of these estimates may approach $30 \%$ for this level of detail for several reasons.

- Combined cycle fuel use quantities in this initial evaluation do not precisely match available purge gas energy. 
- Smaller combined cycles may not perform as estimated.

- Smaller gas turbines in Cases 3 and 4 may not be able to use purge gas as a fuel.

- Gas turbines may require additional steam injection to meet NOx emission limits.

- Revised gasifier steam production and process steam requirements for the ASU and methanol plant will change the steam turbine power output.

Selected CEP configurations will require detailed system matching, flexibility evaluations, and design adjustments as necessary. In addition, a detailed evaluation of the two methanol synthesis processes will help to determine the scenario with the least cost of ownership.

Estimated emissions for all six CEP cases are listed in Table 5.2.3. Cases 1 through 4 are estimated combined cycle emissions, and Cases 5 and 6 are estimated emissions from package boilers. Nitrogen oxides (NOx) and carbon monoxide (CO) emissions are unknown for Cases 5 and 6.

Emissions were estimated but not calculated in detail during this conceptual design effort, so further NOx abatement measures may be needed beyond the estimated steam injection. The relatively high concentration of $\mathrm{CO}$ in the synthesis gas could increase NOx emissions because of the higher flame temperature of $\mathrm{CO}$ compared to that of the natural gas.

If final design calculations indicate the need for further NOx mitigation, the synthesis gas could be diluted with either more steam or nitrogen as a means of reducing NOx emissions, given that nitrogen is expected to be available from the ASU. Elevated CO concentrations in the synthesis gas would also require some design modifications to the fuel delivery system and the addition of a fuel leak detection system due to toxicity and flammability of the fuel. 
Table 5.2.3: Estimated CEP Power Plant Effluent Stream Results

\begin{tabular}{|c|c|c|c|c|c|c|}
\hline Case Number & 1 & 2 & 3 & 4 & 5 & 6 \\
\hline Solid Fuel Type & Petcoke & Coal & Petcoke & Coal & Petcoke & Coal \\
\hline Conversion Case & Low & Low & High & High & High & High \\
\hline MEOH Process & LPMEOH $^{\mathrm{TM}}$ & LPMEOH $^{\mathrm{TM}}$ & LPMEOH $^{\mathrm{TM}}$ & LPMEOH TM $^{\mathrm{TM}}$ & GPMEOH & GPMEOH \\
\hline \multicolumn{7}{|l|}{ Weight flow, lb/hr } \\
\hline $\operatorname{Ar}$ & 43,715 & 46,040 & 9,588 & 9,588 & 1,681 & 1,960 \\
\hline $\mathrm{CO}$ & 28 & 28 & 6 & 6 & & \\
\hline $\mathrm{CO}_{2}$ & 392,027 & 375,721 & 25,717 & 25,717 & 18,323 & 19,792 \\
\hline $\mathrm{H}_{2} \mathrm{O}$ & 209,587 & 217,475 & 76,698 & 76,698 & 26,728 & 33,706 \\
\hline $\mathrm{N}_{2}$ & $2,034,652$ & $2,033,408$ & 564,874 & 564,874 & 115,990 & 134,628 \\
\hline $\mathrm{NOx}\left(\right.$ as $\left.\mathrm{NO}_{2}\right)$ & 117 & 116 & 25 & 25 & & \\
\hline $\mathrm{O}_{2}$ & 456,531 & 454,999 & 125,606 & 125,606 & 5,211 & 5,879 \\
\hline Total & $3,136,657$ & $3,127,787$ & 802,514 & 802,514 & 167,934 & 195,965 \\
\hline \multicolumn{7}{|l|}{ Composition (Vol\%) } \\
\hline $\overrightarrow{\mathrm{Ar}}$ & 1.0 & 1.1 & 0.8 & 0.8 & 0.7 & 0.7 \\
\hline $\mathrm{CO}$ & 0.0 & 0.0 & 0.0 & 0.0 & 0.0 & 0.0 \\
\hline $\mathrm{CO}_{2}$ & 8.2 & 7.9 & 2.0 & 2.0 & 6.7 & 6.1 \\
\hline $\mathrm{H}_{2} \mathrm{O}$ & 10.7 & 11.1 & 14.5 & 14.5 & 23.8 & 25.5 \\
\hline $\mathrm{N}_{2}$ & 66.9 & 66.9 & 69.1 & 69.1 & 66.2 & 65.3 \\
\hline $\mathrm{NOx}\left(\right.$ as $\left.\mathrm{NO}_{2}\right)$ & 0.0 & 0.0 & 0.0 & 0.0 & 0.0 & 0.0 \\
\hline $\mathrm{O}_{2}$ & 13.1 & 13.1 & 13.5 & 13.5 & 2.6 & 2.5 \\
\hline Total & 100.0 & 100.0 & 99.9 & 99.9 & 100.0 & 100.0 \\
\hline \multicolumn{7}{|l|}{$\mathrm{CO}$} \\
\hline ppmv & 9.3 & 9.3 & 7.4 & 7.4 & & \\
\hline ppmvd, $15 \% \mathrm{O}_{2}$ & 10.0 & 10.0 & 10.0 & 10.0 & [1] & [1] \\
\hline \multicolumn{7}{|l|}{$\underline{\mathrm{NOx}}\left(\right.$ as $\left.\mathrm{NO}_{2}\right)$} \\
\hline ppmv & 23.4 & 23.2 & 18.6 & 18.6 & & \\
\hline ppmv,d, $15 \% \mathrm{O}_{2}$ & 25.0 & 25.0 & 25.0 & 25.0 & [1] & [1] \\
\hline
\end{tabular}

[1] Unknown 


\subsubsection{CEP Financial Modeling Case Study Results}

The economic model developed for evaluating the IGCC and methanol facility was refined. The basic outline of the CEP model scope did not change from earlier work and is shown in Figure 5.3.1.1. The model includes feedstocks of petroleum coke or coal to the IGCC and methanol production unit. This block produces power, methanol and has synthesis gas, nitrogen and steam as auxiliary products, which can be used by a fenceline methanol-based chemical manufacturing plant. Excess power can be sold to external markets. Because the IGCC and methanol units are about $80 \%$ reliable, makeup sources are required to keep the fenceline plant operational while repairs and maintenance are completed.

\section{Figure 5.3.1.1: CEP Financial Model Scope \& Boundary Diagram}

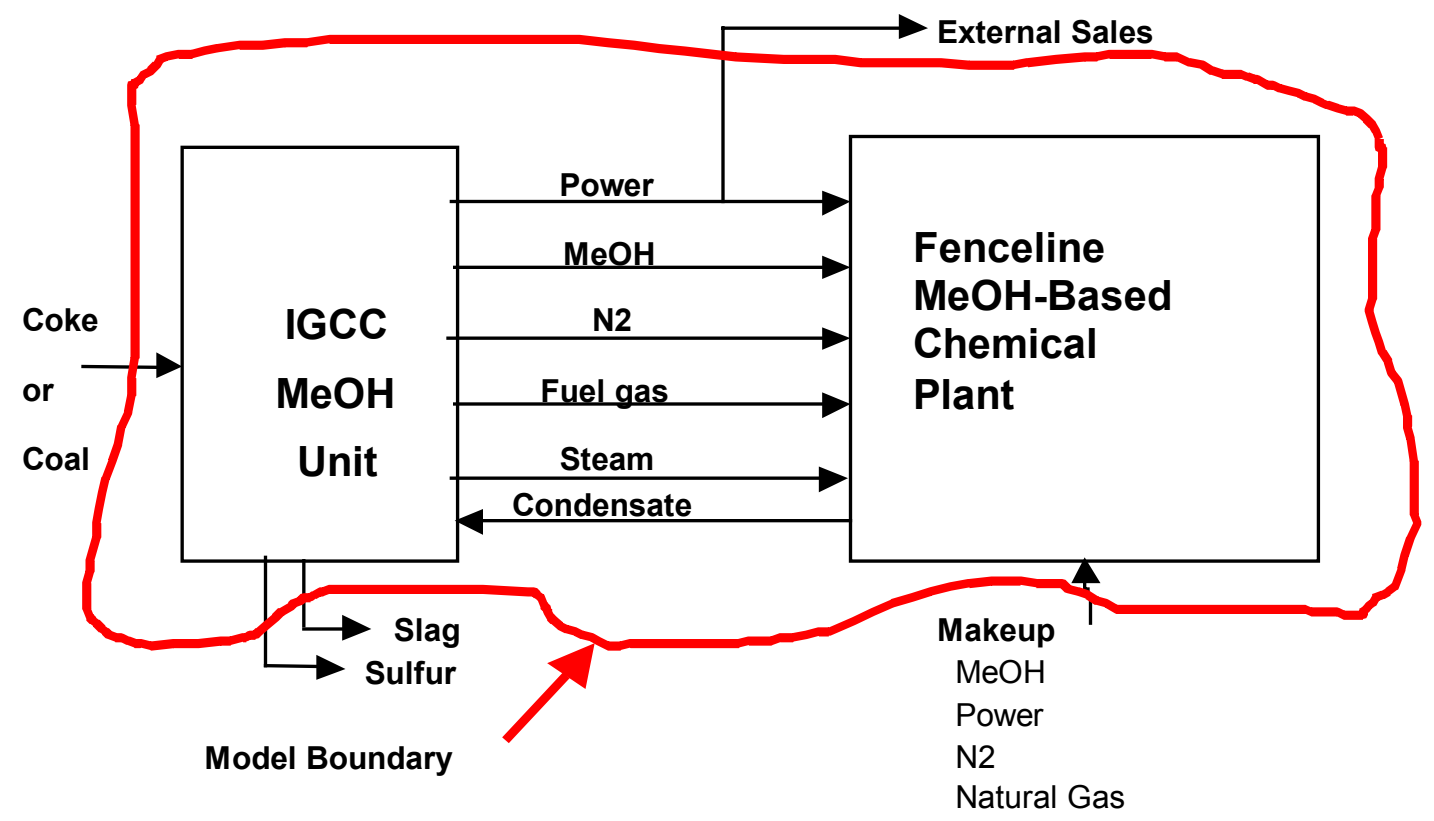

The IGCC and methanol production unit blocks are unchanged and a more detailed view is shown in Figure 5.3.1.2. The coal gasifier consumes coal or petroleum coke slurry as a fuel source and is fed with oxygen to produce synthesis gas. Slag and sulfur are produced as byproducts. Nitrogen from the ASU is used for process requirements. The synthesis gas can be used to generate power, produce methanol or supply fuel gas for specific needs. The coal gasifier is a net steam generator and this steam is used to 
generate electrical power, as well as for various process uses in the IGCC/methanol plants. Steam can also be exported to the fenceline facility.

\section{Figure 5.3.1.2: Financial model Scope for IGCC \& Methanol Plant Diagram}

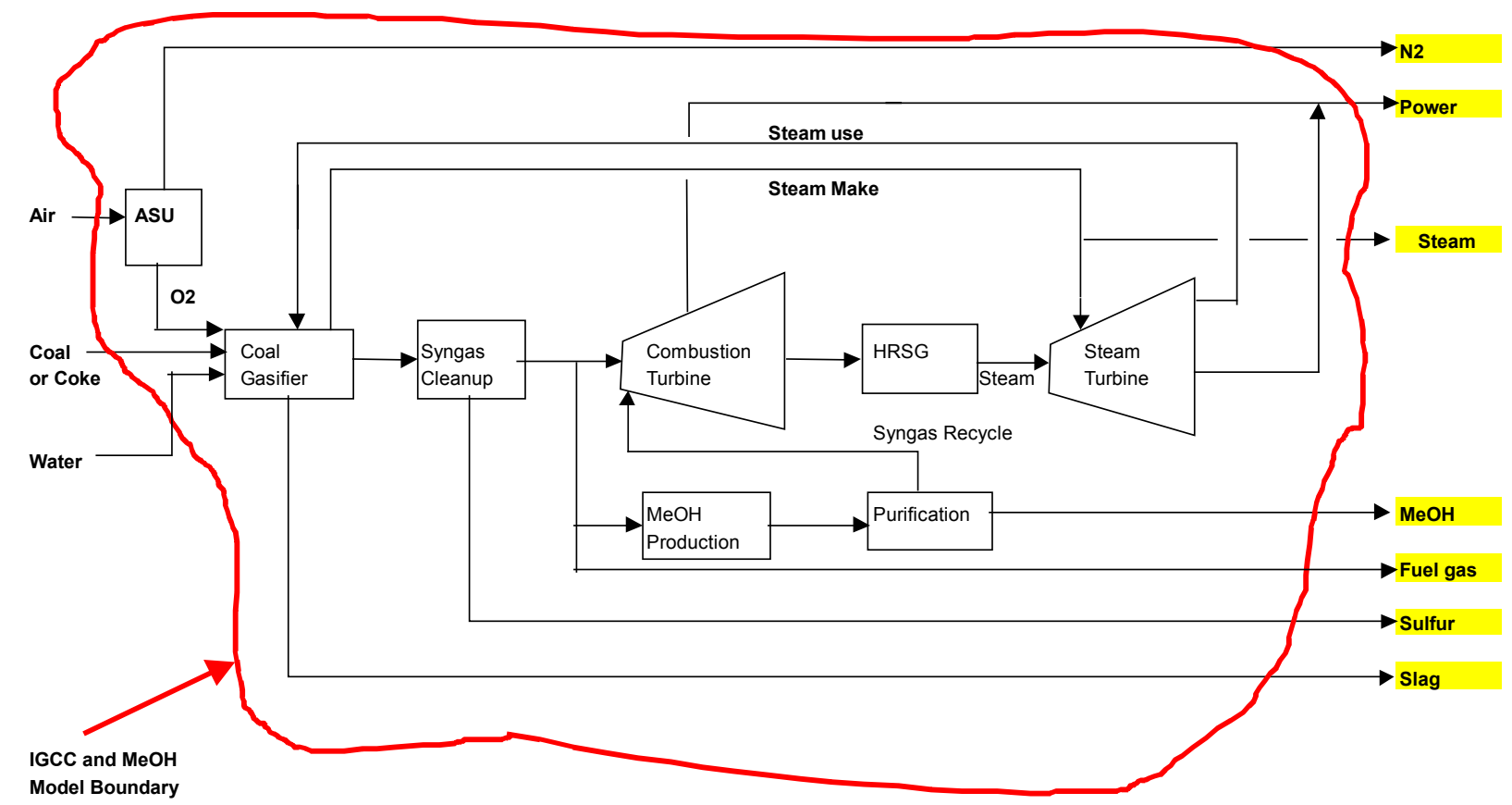

Synthesis gas, which is fed to the methanol production plant, may be only partially converted to methanol and the unreacted material is passed back to the combined cycle power generation block for combustion. The combustion turbine generates power directly and hot exhaust gases are used to raise steam in a Heat Recovery Steam Generator (HRSG). This steam drives a steam turbine to generate additional power or could be utilized by the fenceline plant.

The CEP financial model considers a number of plant configurations for a fixed size coal gasification plant. The gasifier size is based on the state of the demonstrated technology. In some of the configurations, the combined cycle plant (combustion turbine + HRSG + steam turbine) component sizes were adjusted to combinations very different than would be expected for a conventional operation due to the integration with the methanol synthesis and the fenceline methanol-based chemical production 
facilities. The cases were developed to explore a spectrum of plant configurations to understand where the optimal economics could be.

Case $\mathbf{0}$ is an all power production configuration and is used as a benchmark of IGCC power generation economics. In this case, there is no methanol production and the coal gasifier feeds all of the synthesis gas produced directly to a combustion turbine combined cycle unit for electricity production. This case is used just as a comparison to understand the electrical power generation costs.

Case 1 produces methanol with low conversion of synthesis gas using the liquid phase methanol technology $\left(\mathrm{LPMEOH}^{\mathrm{TM}}\right)$. Unreacted synthesis gas is passed to the combined cycle block for power production. This case uses petroleum coke as a fuel.

Case 2 is a replica of Case 1, but uses coal as a feedstock rather than petroleum coke. The coal provides a better balanced synthesis gas and more methanol production is possible.

For a description of balanced synthesis gas, recall that the stoichiometric ratio for methanol production as defined by $[(\mathrm{H} 2-\mathrm{CO} 2) /(\mathrm{CO} 2+\mathrm{CO})]$, is equal to 2 . Synthesis gas technologies that use natural gas as feedstock can achieve stoichiometric ratios between 1.7-3.0. Ratios of greater than 2 are most common and this type of synthesis gas would have excess hydrogen. Synthesis gases with stoichiometric ratios of 2 or greater are termed as balanced gas.

Case 3 produces methanol with maximized conversion of synthesis gas using the liquid phase methanol technology $\left(\mathrm{LPMEOH}^{\mathrm{TM}}\right)$. It includes a water-gas shift reactor and CO2 removal to balance the synthesis gas and maximize methanol production. Unreacted synthesis gas is used for power production. This case uses petroleum coke as fuel. 
Case 4 is a replica of Case 3, but uses coal as a feedstock. Since Cases 3 and 4 include gas-balancing equipment, the methanol production rates are not affected by fuel choice.

Case 5 produces methanol with maximized conversion of synthesis gas using conventional gas phase methanol technology (GPMEOH). A slight amount of synthesis gas that is not converted is fired in a package boiler to raise process steam. This case uses petroleum coke as fuel.

Case 6 is a replica of Case 5 , but uses coal as a feedstock.

The capital and operating costs for each of these cases was estimated, along with the methanol, steam, and electricity production capabilities. Each of these plant configurations could be considered as a stand-alone plant which sells electricity and/or methanol to the marketplace, or in a fenceline configuration where some (or all) of the products go to a neighboring chemicals complex. The financial model allows each of the cases to be adjusted to consider the requirements of a fenceline plant. Table 5.3.1.1 below summarizes the seven cases in a "stand-alone" mode, without fenceline integration. 
Table 5.3.1.1: Fenceline Plant CEP Case Studies

\begin{tabular}{|c|c|c|c|c|c|c|c|}
\hline \multirow[b]{2}{*}{ Parameter (units) } & \multicolumn{7}{|c|}{ Case Numbers } \\
\hline & 0 & 1 & 2 & 3 & 4 & 5 & 6 \\
\hline Fuel & $\begin{array}{l}\text { Pet. } \\
\text { Coke }\end{array}$ & $\begin{array}{l}\text { Pet. } \\
\text { Coke }\end{array}$ & Coal & $\begin{array}{l}\text { Pet. } \\
\text { Coke }\end{array}$ & Coal & $\begin{array}{l}\text { Pet. } \\
\text { Coke }\end{array}$ & Coal \\
\hline Methanol Technology & None & $\begin{array}{l}\text { Liquid } \\
\text { Phase }\end{array}$ & $\begin{array}{l}\text { Liquid } \\
\text { Phase }\end{array}$ & $\begin{array}{l}\text { Liquid } \\
\text { Phase }\end{array}$ & $\begin{array}{l}\text { Liquid } \\
\text { Phase }\end{array}$ & $\begin{array}{l}\text { Gas } \\
\text { Phase }\end{array}$ & $\begin{array}{l}\text { Gas } \\
\text { Phase }\end{array}$ \\
\hline Conversion (\% Btu's) & 0 & $24 \%$ & $34 \%$ & $66 \%$ & $66 \%$ & $70 \%$ & $70 \%$ \\
\hline Fuel used (Tons/day) & 2700 & 2700 & 3280 & 2700 & 3280 & 2700 & 3280 \\
\hline $\begin{array}{l}\text { Synthesis Gas Product } \\
\text { (MMBtu/hr) }\end{array}$ & 2587 & 2587 & 2606 & 2587 & 2606 & 2587 & 2606 \\
\hline $\begin{array}{l}\text { Methanol Product } \\
\text { (tons/day) }\end{array}$ & 0 & 865 & 1221 & 2380 & 2380 & 2515 & 2550 \\
\hline Net Power ${ }^{1}(\mathrm{MW})$ & 412 & 260 & 202 & 5 & -3 & -81 & -85 \\
\hline O\&M (\$MM) & 29 & 32 & 31 & 35 & 35 & 28 & 28 \\
\hline Capital (\$MM) & 582 & 574 & 551 & 525 & 521 & 437 & 435 \\
\hline
\end{tabular}

\subsubsection{CEP Financial Modeling Market Sensitivity Study Results}

Because initial model results showed great price sensitivity to predicted power costs, an external firm, Energy Ventures Analysis, Inc. (EVA), was commissioned to provide forward price projections for power purchased at the Cinergy Hub [1]. The study cost of $\$ 8500$ included projections for the North American Electric Reliability Council's (NERC), subregion of Michigan, excluding the Upper Peninsula (or MECS) at no extra cost. The projections also included a 15-year forecast of wholesale power prices for the NERC sub-regions of southern Ohio, Indiana, Kentucky, and West Virginia. The model included marginal generating cost factors including:

- Seasonally adjusted fuel market price and transport costs 
- Fuel heat rate

- $\mathrm{SO}_{2}$ and $\mathrm{NO}_{\mathrm{x}}$ emission costs

- Variable operating and maintenance costs

- Capital cost for peaking power plants

- Net capacity with expected scheduled and unplanned outages plus seasonal capacity variation

The study also considered electricity demand growth and evaluated cases where the power costs are inflated by constraints on the amount of power that can be imported (Constrained Transmission Case) or by natural gas prices in the $95^{\text {th }}$ percentile of price projections. Summary results are shown in Figure 5.3.2.1.

Figure 5.3.2.1: CEP Electricity Price Projections (in 2001 dollars)

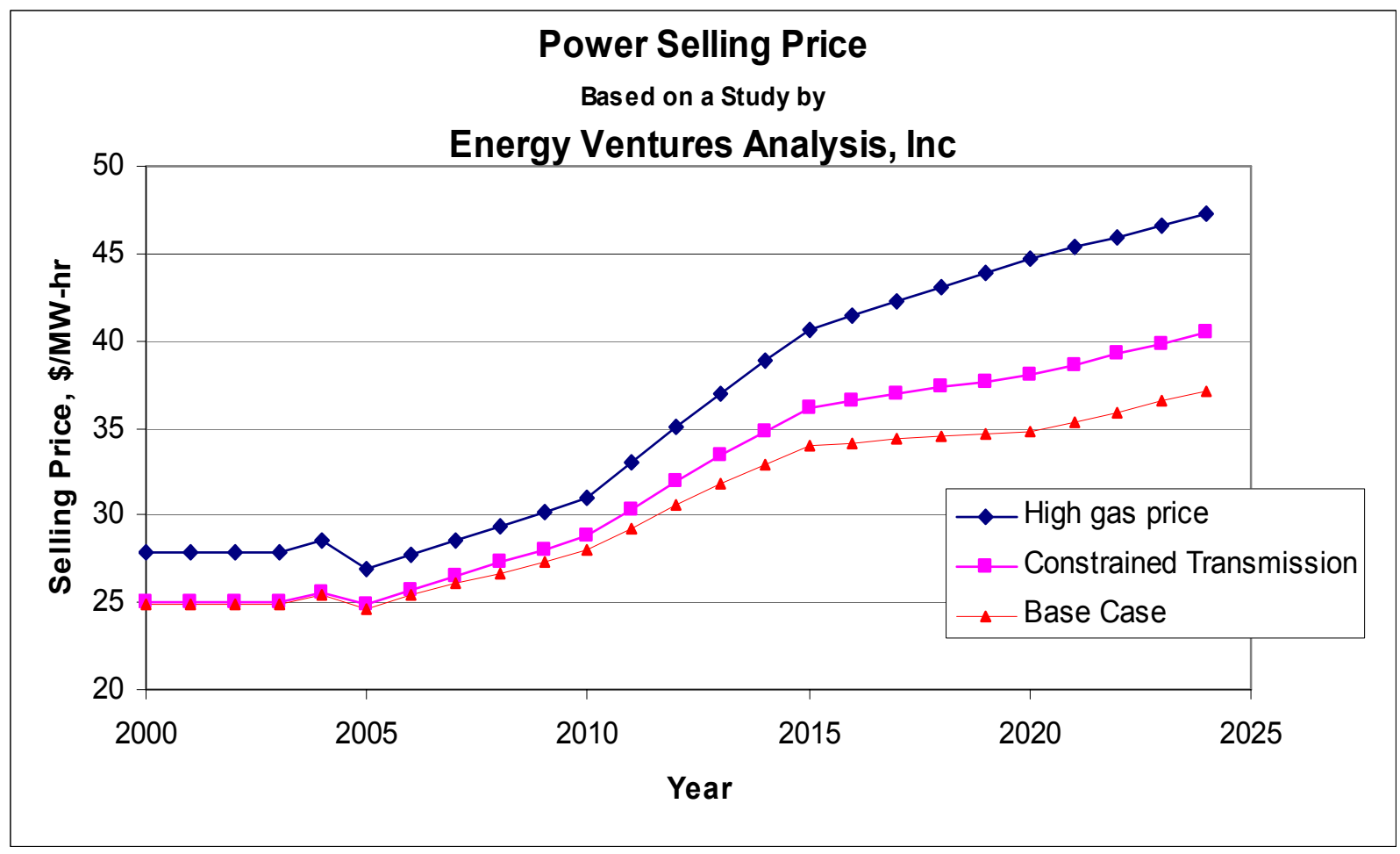

Results through 2020 are determined directly from the study, and results to 2024 (the extent of the economic model 20 year evaluation period) were extrapolated. Results 
shown for 2000-2002 are assumed to be the same as the 2003 prediction from the study, reflecting the flat power price projection for the period of 2000 through 2003. This simplification was made because the economic model is insensitive to power prices while the combined gasification and methanol CEP construction occurs in the early project years.

Other feedstocks and products associated with the IGCC-Methanol plant and the fenceline methanol-based chemical plant were evaluated in sensitivity studies to understand market conditions that could make the plant profitable. Ranges studied are summarized in Table 5.3.2.1.

Table 5.3.2.1: Feedstock and Product Prices Considered for Initial Sensitivity

\begin{tabular}{|c|c|c|}
\hline Feedstock or Product & Purchase Cost & Sales Price \\
\hline Petroleum Coke & $\$ 0.50 / \mathrm{MM} \mathrm{Btu}$ & \\
\hline Coal & $\$ 1.25 / \mathrm{MM} \mathrm{Btu}$ & \\
\hline Natural Gas & $\$ 3.50 / \mathrm{MM} \mathrm{Btu}$ & \\
\hline Power & Adapted from EVA & Adapted from EVA \\
\hline Methanol & $\$ 0.30-\$ 0.50 /$ gallon & $\$ 0.30-\$ 0.50 /$ gallon \\
\hline
\end{tabular}

\subsubsection{CEP Financial Modeling Case-Integration Sensitivity Study Results}

Economic values for the project were determined by calculating Net Present Values (NPVs) for costs and revenues. In the cases where the gasification and methanol plants were considered as a "stand-alone" plant selling power and methanol to the market, this included all costs and revenues.

Where integration with a fenceline methanol-based chemical plant was considered, the gasification and methanol plant costs and revenues and the fenceline chemical plant's costs, which would change as a result of the integration, were included. Sensitivity 
study factors (e.g. methanol price) were adjusted to drive the NPV to zero to calculate conditions required to get the internal rate of return (IRR) equal to the discount rate.

In Figure 5.3.3.1 a screening of the six cases was conducted at the extremes of the power cost curves (base case and high gas price case), considering the six cases both as "stand-alone" facilities which produce and market methanol and power, and also as integrated facilities that supply methanol and utilities to a methanol-based chemical plant at the fenceline. The market methanol price at which these scenarios would generate a 20 -year NPV of zero at a $12 \%$ discount rate (with $3 \%$ inflation) was considered. Delivered fuel costs for coal and petroleum coke shown in Table 5.3.2.1 were included.

For the "integrated" cases, a fenceline methanol-based chemical plant was considered. Specifically, Dow Corning's Carrollton, Kentucky silicones production facility was modeled assuming 357,000 tons/year methanol, $3.3 \times 10^{6}$ million Btu/year for natural gas and about $\$ 2$ million/year expenditure on other operating and maintenance costs for site utilities.

The model assumes that a pro-rated share of these costs is still borne by the chemicals plant during times when the gasification and methanol facilities are off-line due to an assumed $80 \%$ reliability. No allowances were made for the utilities startup and shutdown costs at the fenceline methanol-based chemical plant site. 
Figure 5.3.3.1: Financial Case Screening Results

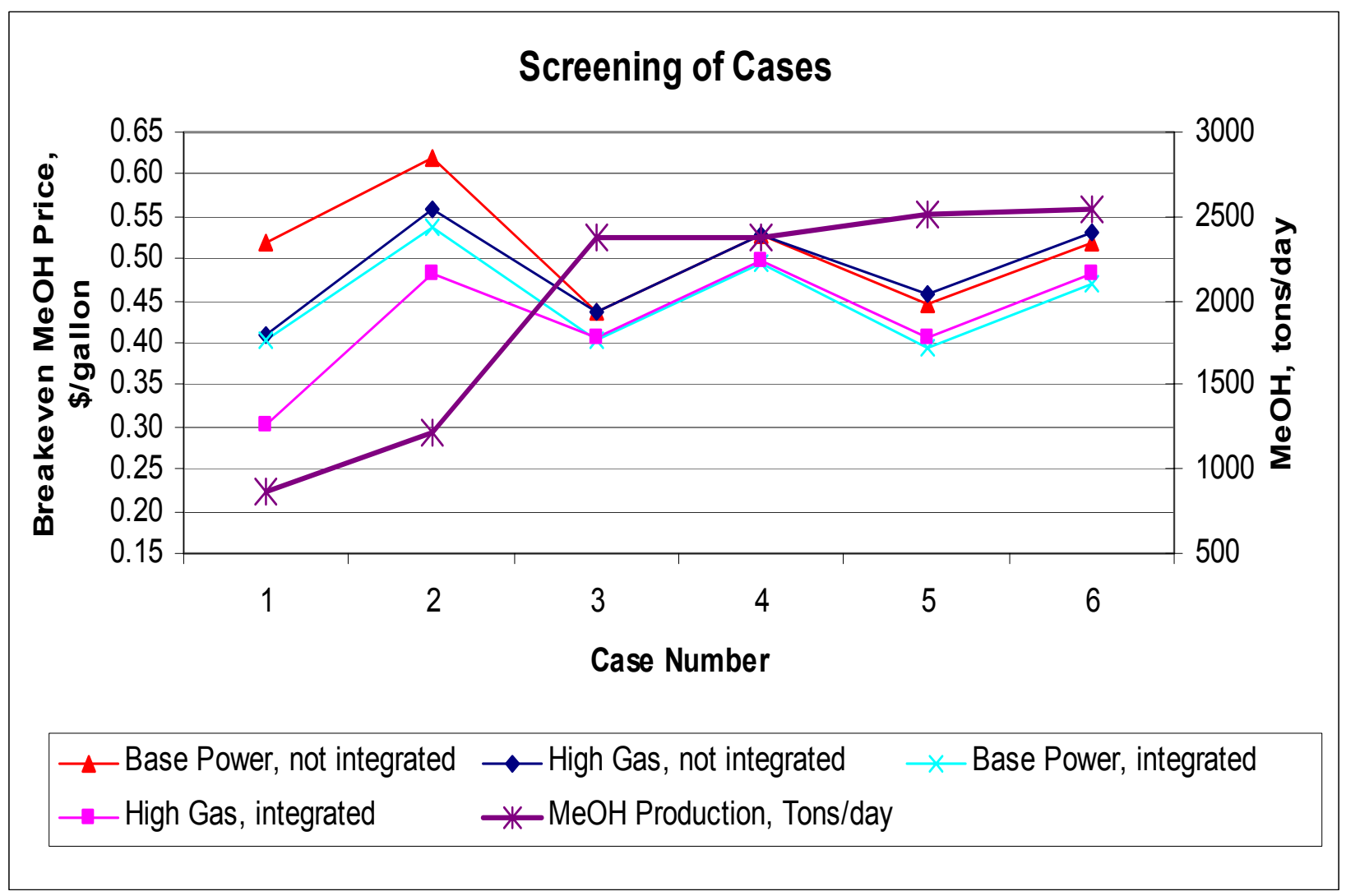

Results indicate that the best economics are achieved by plant configurations which:

- use petroleum coke feedstock (\$0.50/MM Btu delivered cost, vs. $\$ 1.25$ for coal)

- are integrated with the chemicals facility (synergy providing $\sim 5 \phi /$ gallon advantage for high methanol production cases and more for high power cases.)

Furthermore, those cases 1 and 2 that make more power and less methanol are more sensitive to the range of power pricing.

\subsubsection{CEP Financial Modeling Break-Even Sensitivity Study Results}

In Figure 5.3.4.1 the Case 1 break-even power selling prices were determined, considering methanol market prices in the range of 30-50 $/$ gallon, and petroleum coke prices of $\$ 0.50-\$ 1.25 / \mathrm{MMBtu}$ delivered. This covers a market price range of interest for methanol and considers petroleum coke costs from a realistic delivered price 
(\$0.50/MMBtu) all the way up to the delivered coal price $(\$ 1.25 / \mathrm{MMBtu}$, although the plant would run differently on coal). In other words, Cases 2, 4, and 6 (coal cases) perform differently than 1,3 , and 5 .

The break-even power prices determined are in year 2001 dollars and are treated with inflation, but no other escalation. On the EVA plot in Figure 5.3.2.1, for example, a $\$ 30 / M W-h r$ power selling price would be shown as a horizontal line. The model includes inflation in the cash flow analysis. This case offers some promise across these methanol and fuel price ranges when the EVA projected power price curves are compared against the breakeven power prices predicted.

Figure 5.3.4.1: Breakeven Selling Price Screening Results

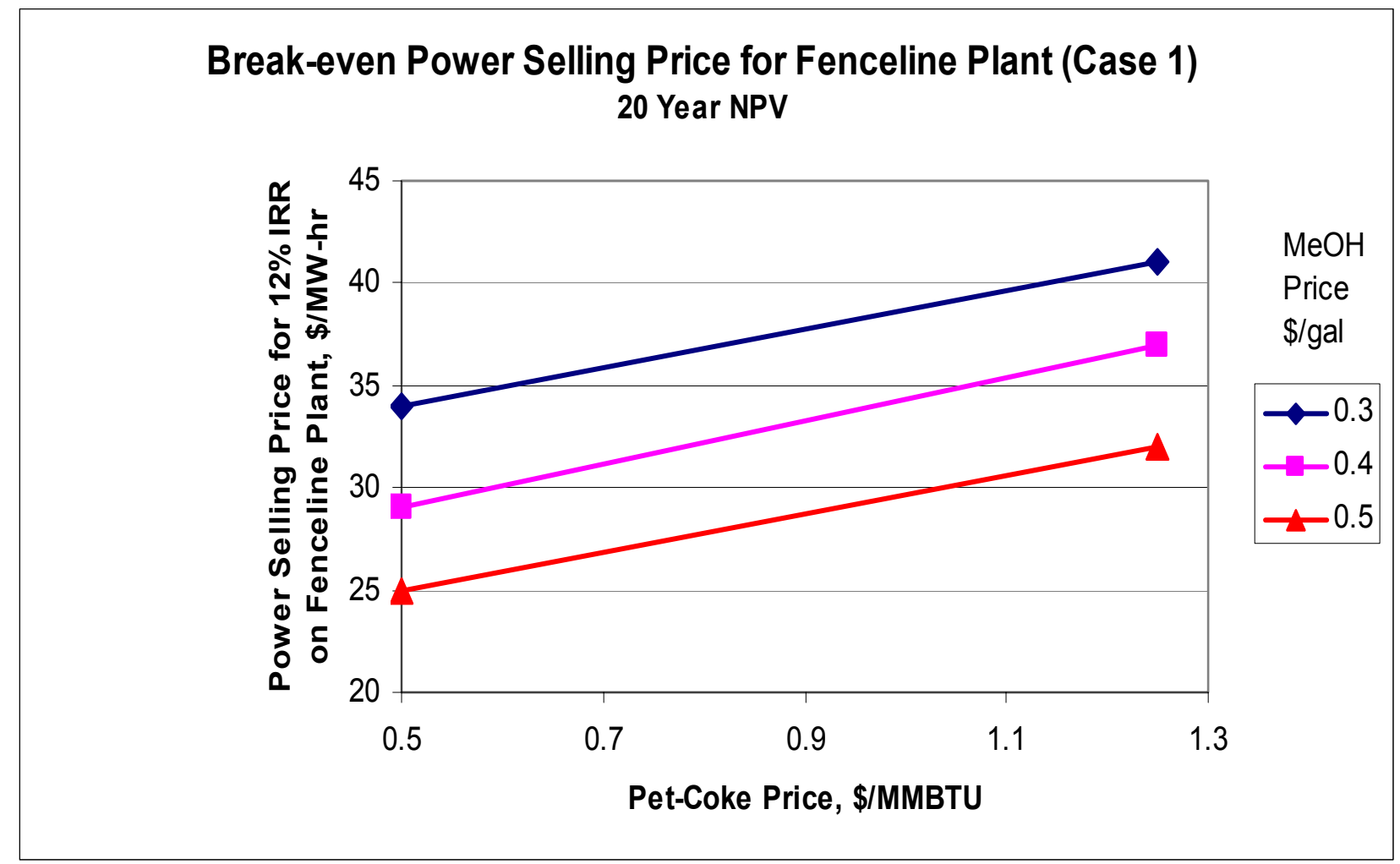

The results from these studies are also shown in Table 5.3.4.1 below. This table is similar to Table 5.3.1.1 but includes the effects of the fenceline plant integration. This influences the amount of power and methanol sold, as well as the capital costs. 
Table 5.3.4.1: Case Studies (with Fenceline Plant) Screening Results

\begin{tabular}{|l|c|c|c|c|c|c|c|}
\hline & \multicolumn{7}{|c|}{ Case Numbers } \\
\hline \multicolumn{1}{|c|}{ Parameter (units) } & $\mathbf{0}$ & $\mathbf{1}$ & $\mathbf{2}$ & $\mathbf{3}$ & $\mathbf{4}$ & $\mathbf{5}$ & $\mathbf{6}$ \\
\hline $\begin{array}{l}\text { Solid Fuel Costs } \\
\text { (\$/MMBtu) }\end{array}$ & 0.50 & 0.50 & 1.25 & 0.50 & 1.25 & 0.5 & 1.25 \\
\hline $\begin{array}{l}\text { Natural Gas Cost } \\
\text { (\$MMBtu) }\end{array}$ & 3.50 & 3.50 & 3.50 & 3.50 & 3.50 & 3.50 & 3.50 \\
\hline Capital Cost (\$MM) & 571 & 562 & 539 & 507 & 503 & 426 & 422 \\
\hline O \& M Cost (\$MM/year) & 29 & 31 & 31 & 35 & 35 & 28 & 28 \\
\hline Power Export (MW) & 360 & 208 & 150 & -47 & -55 & -111 & -115 \\
\hline $\begin{array}{l}\text { Methanol Produced } \\
\text { (tons/day) }\end{array}$ & 0 & 865 & 1221 & 2380 & 2380 & 2515 & 2550 \\
\hline $\begin{array}{l}\text { Breakeven Power } \\
\text { (\$/MW-hr at 27ф/gallon } \\
\text { methanol price) }\end{array}$ & 28 & 35 & 52 & & & & \\
\hline $\begin{array}{l}\text { Methanol Breakeven } \\
\text { (\$/gallon at Base power) }\end{array}$ & N/A & 0.40 & 0.54 & 0.40 & 0.49 & 0.40 & 0.47 \\
\hline $\begin{array}{l}\text { Methanol Breakeven } \\
\text { \$/gallon at high gas } \\
\text { power price) }\end{array}$ & N/A & 0.30 & 0.48 & 0.40 & 0.50 & 0.41 & 0.48 \\
\hline
\end{tabular}

The sensitivity of break-even methanol price to fuel price and power selling price was also evaluated for an integrated gasification, methanol synthesis, and fenceline methanol-based chemical facility. Figure 5.3.4.2 shows the breakeven methanol price at which the plant 20 year NPV goes to zero at a $12 \%$ rate of return. 
Figure 5.3.4.2: Screening Results for Breakeven Methanol Price

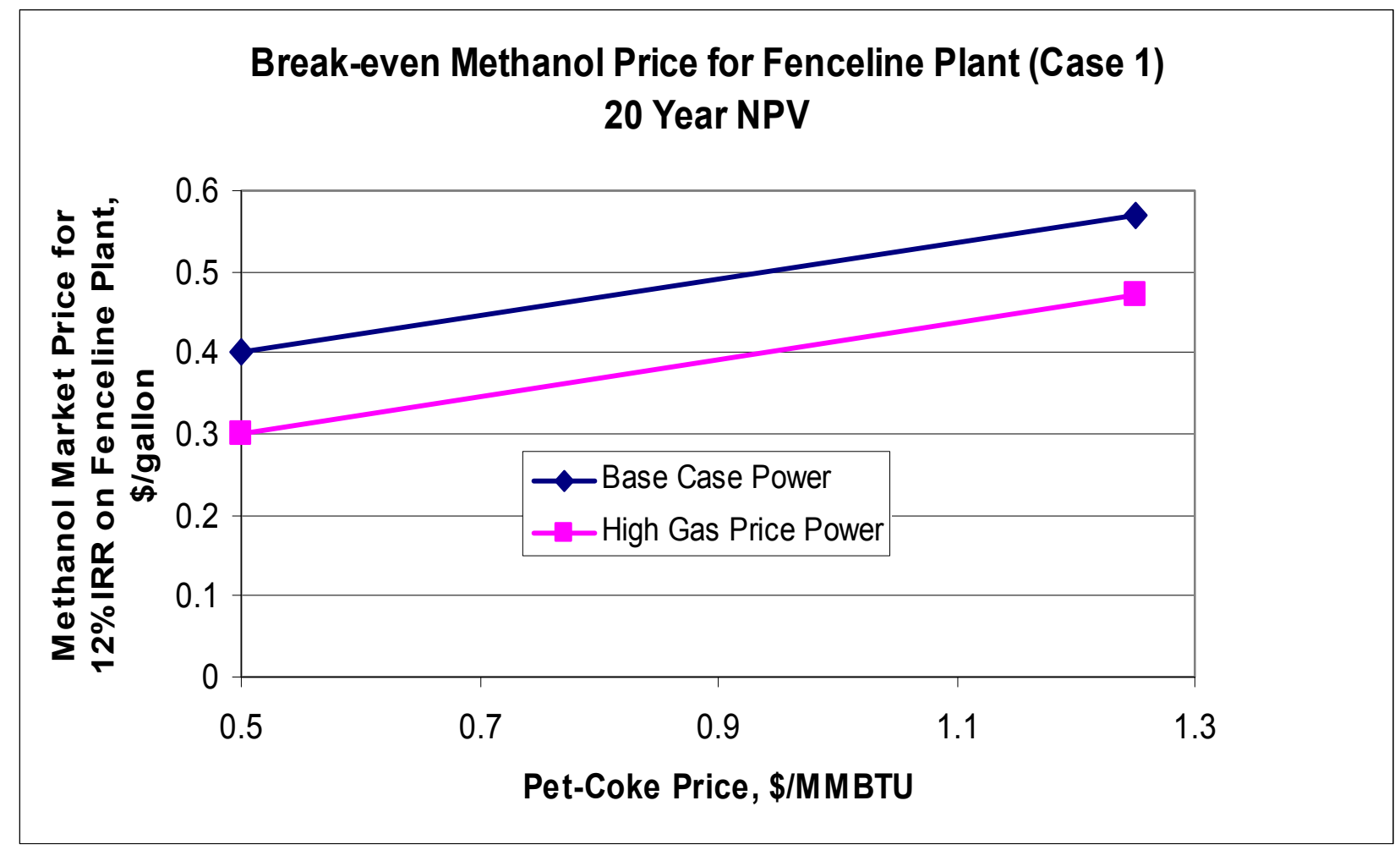

Not surprisingly, higher power selling prices and lower fuel costs allow the plant to operate with a lower required methanol price and still produce revenues required to support a $12 \%$ internal rate of return. Given the methanol market price history, the

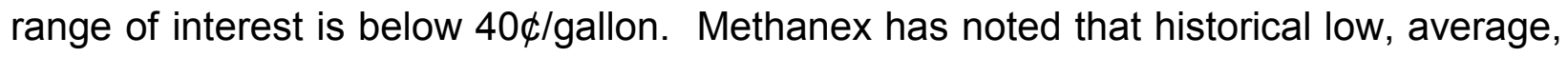
and high prices for methanol are typically $22 \phi / g a l l o n, 45 \phi / g a l l o n$, and $65 \phi / g a l l o n$, respectively.

When this is considered in a log-normal probability distribution, a plot would look something like Figure 5.3.4.3. Methanol at a $40 \phi / g a l l o n$ price would beat the market about 31 percent of the time (31\% of the area under the probability curve). A price of $30 \phi /$ gallon outpaces the market price about $98 \%$ of the time. 
Figure 5.3.4.3: Methanol Market Price Distribution Estimate

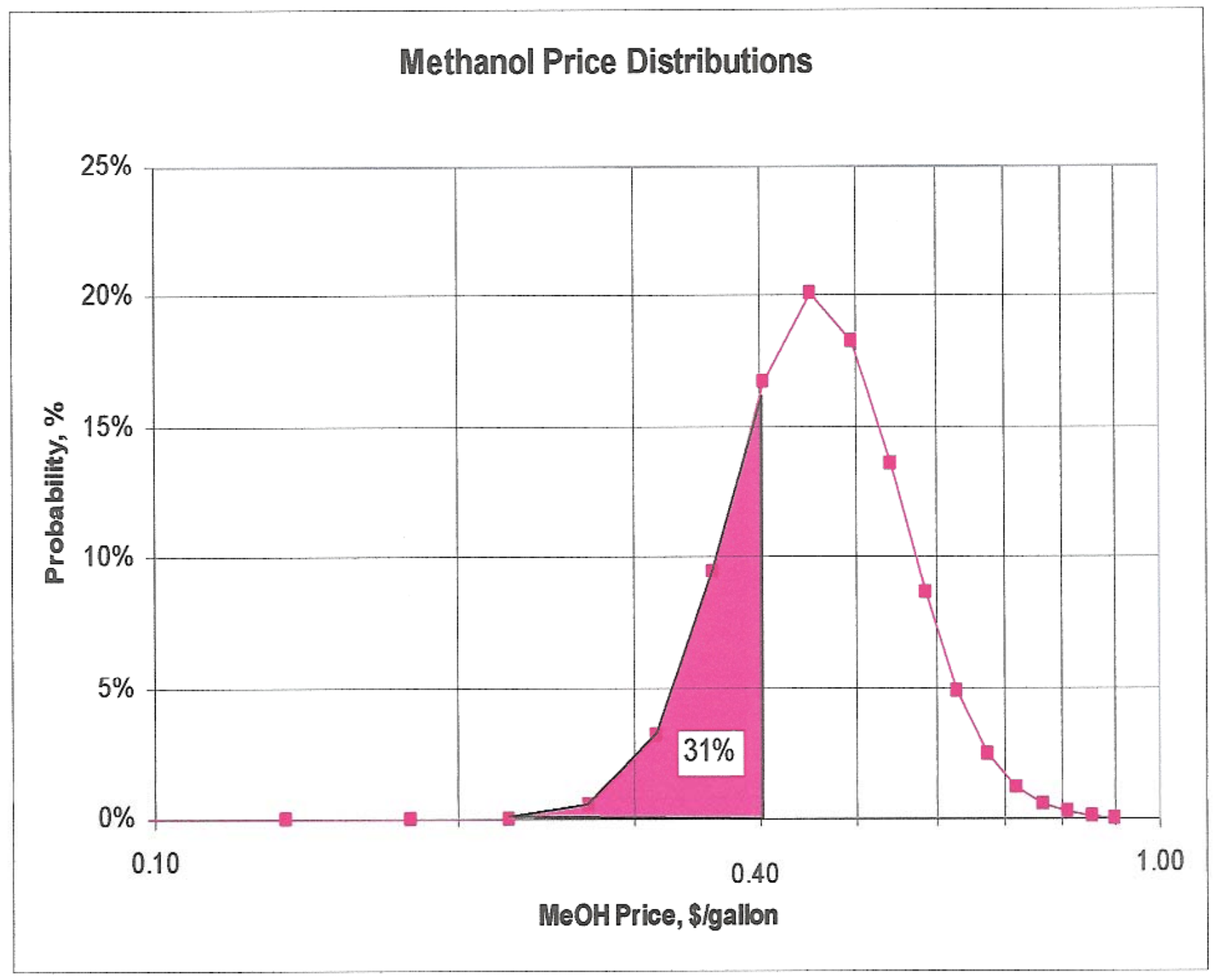

\subsubsection{CEP Financial Modeling Project Return Sensitivity Study Results}

Sensitivity of project NPV to the payback time period and to the discount rate were also considered. Due to the high capital investment, the breakeven methanol prices required to service the investment climb dramatically if either the expected rate of return (discount rate) increases or the payback period is shortened to ten years as shown in Figure 5.3.5.1 (the power and methanol scales have been positioned to superimpose the 10 year and 20 year lines): 
Figure 5.3.5.1: Break-Even Methanol \& Power Price; Return \& Payback Sensitivity

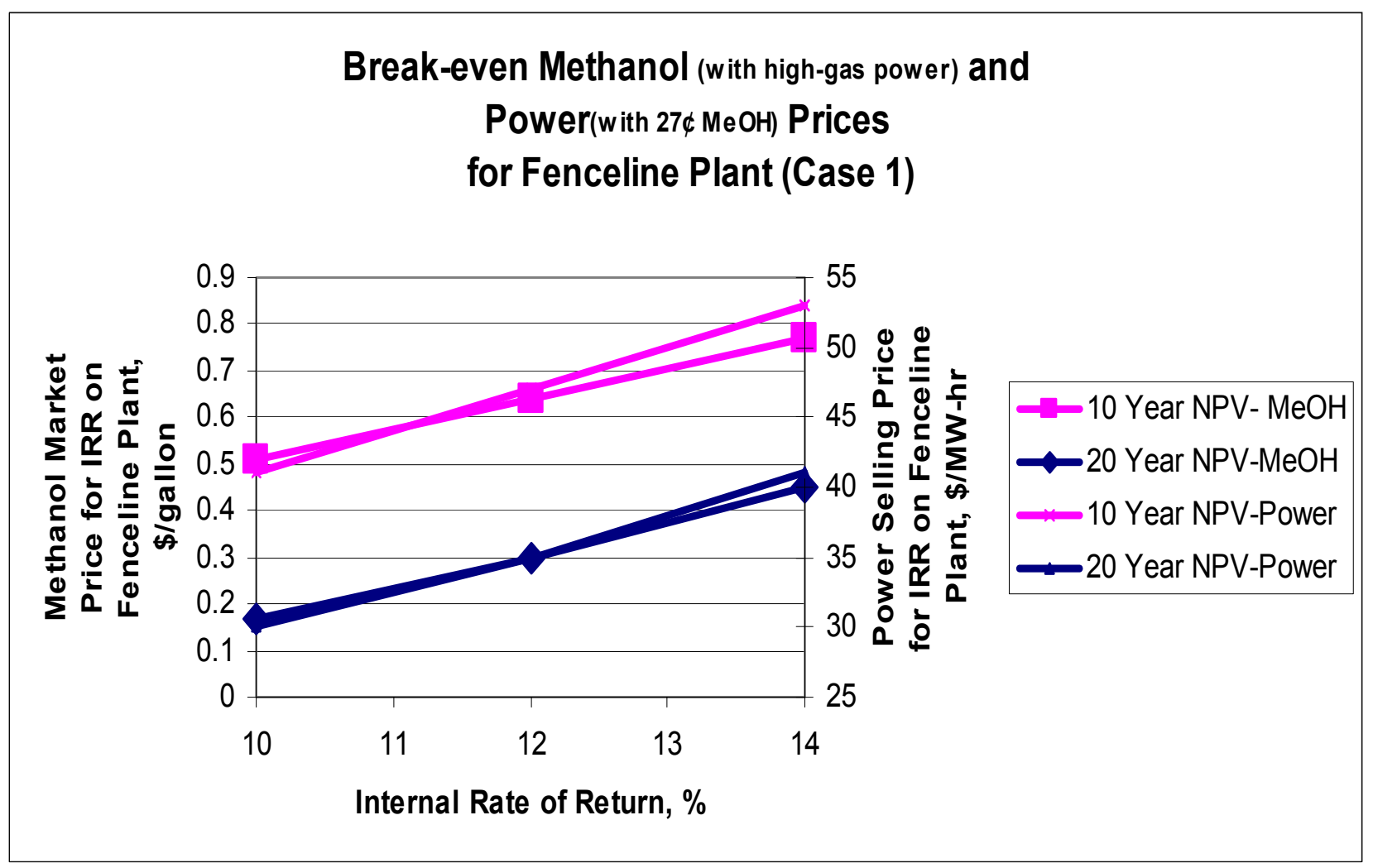

\subsubsection{CEP Financial Modeling Plant Reliability Sensitivity Study Results}

Sensitivity to plant utilization was also explored. Figure 5.3.6.1 shows the result on breakeven methanol price if the $80 \%$ reliability is not sustained for the duration of the payback period. If the reliability slips by as little as $5-10 \%$ from the feasible assumption, it puts the plant economics at serious risk because the required methanol price to provide a $12 \%$ return climbs to $40-45 \phi /$ gallon. 
Figure 5.3.6.1: Break-Even Methanol Price; Plant Reliability Sensitivity

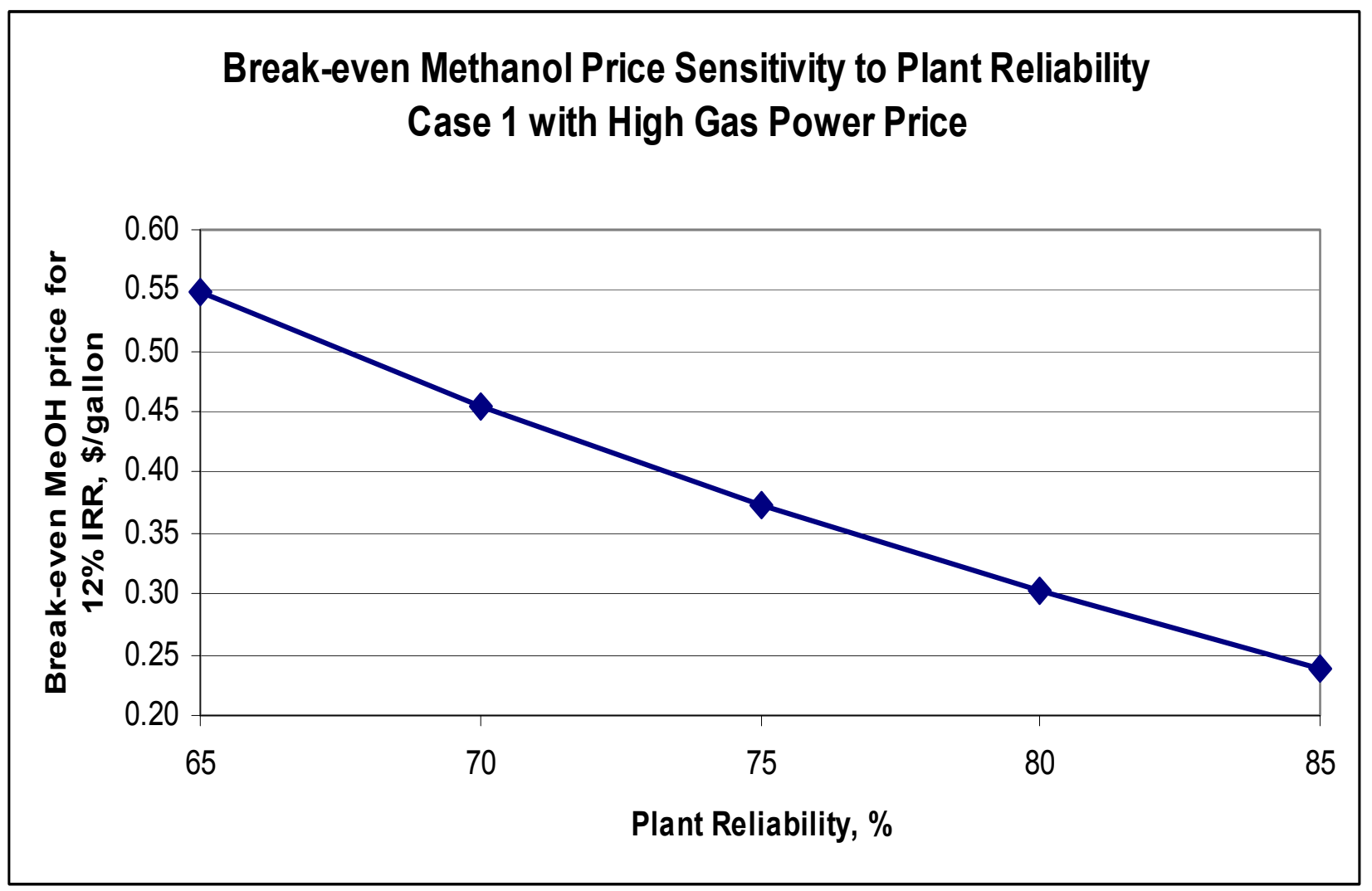




\subsection{CONCLUSIONS}

Under the guidance of the Project Management Plan, Phase I will be performed by all team members, GEC, Air Products, Methanex, Dow Corning, Siemens Westinghouse, and Dow Chemical. The Phase I focus is on development of the advanced economic model, analysis of the commercialization potential for the gasification to methanol and power coproduction concept for future CEP, and preliminary engineering and environmental work for implementation of the methanol production addition at WREL for the IMPPCCT demonstration. GEC will utilize the analysis of potential feedstocks to the gasification section, develop a preliminary site layout, determine synthesis gas quantities available to IMPPCCT, assess final synthesis gas cleanup needs, provide the preliminary environmental assessment, review modifications and tie-ins to the existing infrastructure at the WREL site, and work jointly with Air Products and Methanex to develop the most advantageous economics for IMPPCCT based on either the liquid or gas phase methanol processing units. Air Products has completed the review and application of the $\mathrm{LPMEOH}^{\mathrm{TM}}$ Process with methanol purification systems resulting in development of the methanol unit process package.

The team furthered efforts to analyze the domestic methanol market, investigated the integration issues related to sour synthesis gas treatment, and examined other criteria needed to develop a financial model for full-scale implementation of this gasification to methanol and power coproduction concept. In addition, the consortium continued efforts to define several coproduction plant concepts for a successful CEP and made progress toward financial modeling and sensitivity analyses for these CEP concepts.

During the reporting period work was furthered to support the development of capital and operating cost estimates associated with the installation of liquid or gas phase methanol synthesis technology in a CEP utilizing the six cases scenarios previously defined. 
Continued development of the plant economic model was accomplished by providing combined cycle performance data. Performance and emission estimates for gas turbine combined cycles were based on revised methanol purge gas information.

The economic model was used to evaluate project returns with various market conditions and plant configurations and was refined to correct earlier flaws. Updated power price projections were obtained and incorporated in the model.

\subsection{IGCC Performance and Emission Estimation Conclusions}

Resulting from the case development work and the data produced from that effort, the low conversion CEP cases are appropriate for commercial sites where power, steam, and methanol are useful products but power is desired at higher thermal conversion quantities (heating value basis) compared to methanol.

Similarly, the high conversion CEP cases are appropriate for use at commercial sites where power is not as important as steam and methanol production, defining the highest envelope of methanol synthesis expected from the commercial embodiment design options.

The high conversion CEP cases utilize the same E-GAS ${ }^{\mathrm{TM}}$ gasification technology as the low conversion CEP cases; however methanol synthesis may be either the $\mathrm{LPMEOH}^{\mathrm{TM}}$ liquid phase process from Air Products, or the conventional gas phase process from Methanex. Conversion efficiency is anticipated to be similar for both processes since they both require balanced synthesis gas to achieve maximum methanol production.

The low-conversion cases (Cases 1 and 2) generate enough purge gas to fuel large industrial gas turbine combined cycles such as ones utilizing the Siemens Westinghouse W501D5A turbine model. 
The CEP high conversion cases generate small purge gas streams when compared to the low conversion cases, but are still intended for power production. For Cases 3 and 4 , candidate power systems were selected from a list of smaller commercial combined cycles using between 17 and $150 \mathrm{MWt}$ (60 to $500 \mathrm{MBtu} / \mathrm{h}$ ) of fuel input. The Rolls Royce RB11 combined cycle selected for high-conversion Cases 3 and 4 was the only $60-\mathrm{Hz}$ machine with fuel requirements within $20 \%$ of the thermal input.

Economic evaluations indicate that the purge gas streams in Cases 5 and 6 are not suited to a combined cycle, so the estimates for these cases are for package boilers with $20 \%$ excess air.

The preliminary combined cycle performance estimates in Section 5.2 of this report provide an indication of the level of performance that might be expected for both high and low conversion combined cycle CEP operation. Net power outputs are for the combined cycle only, without deductions for ASU or other plant auxiliary power requirements. None of the values provided imply any guarantees or warranted contractual commitments to actual future gas turbine performance.

These performance estimates are based on simplified plant designs that include only general site conditions, process flow diagrams, and capacities. The uncertainty of these estimates may approach $30 \%$ for this level of detail for several reasons.

- Combined cycle fuel use quantities in this initial evaluation do not precisely match available purge gas energy

- Smaller combined cycles may not perform as estimated

- Smaller gas turbines in Cases 3 and 4 may not be able to use purge gas as a fuel

- Gas turbines may require additional steam injection to meet NOx emission limits

- Revised gasifier steam production and process steam requirements for the ASU and methanol plant will change the steam turbine power output

Selected CEP configurations will require detailed system matching, flexibility evaluations, and design adjustments as necessary. In addition, a detailed evaluation of 
the two methanol synthesis processes will help to determine the high conversion CEP least cost of ownership case scenario.

Estimated emissions for all six CEP cases are detailed in Section 5.2. Cases 1 through 4 are estimated combined cycle emissions, and Cases 5 and 6 are estimated emissions from package boilers. NOx and $\mathrm{CO}$ emissions are unknown for Cases 5 and 6 and will likely require the assistance of consultants outside the consortium to be fully estimated.

Emissions were estimated but not calculated in detail during this conceptual design effort, so further NOx abatement measures may be needed beyond that estimated with steam injection. The relatively high concentration of $\mathrm{CO}$ in the synthesis gas could increase NOx emissions because of the higher flame temperature of $\mathrm{CO}$ compared to that of the natural gas.

If final design calculations indicate the need for further NOx mitigation, the fuel gas could be diluted with either more steam or nitrogen as a means of reducing NOx emissions, given that nitrogen is expected to be available from the ASU. Elevated CO concentrations in the synthesis gas would also require some design modifications to the fuel delivery system and the addition of a fuel leak detection system due to toxicity and flammability of the fuel.

\subsection{CEP Financial Modeling Study Conclusions}

Sensitivity studies show that break-even methanol prices which provide a $12 \%$ return are on the order of $47 \phi-54 \phi / g a l l o n$ using coal, and about $40 \phi /$ gallon for most of the scenarios with $\$ 0.50 / \mathrm{MM}$ Btu petroleum coke as the fuel source. One exception is a high power price-and production-case which can be economically attractive at $30 \phi / g a l l o n$ methanol. This case was explored in more detail, but includes power costs predicated on natural gas prices at the $95^{\text {th }}$ percentile of expected price distributions. In this case, the breakeven price is highly sensitive to the required rate of return, payback period and plant on-line time. The sensitivity is caused mainly by the high capital 
investment required for the CEP facility $(\sim 500 \mathrm{MM}$ for a single train IGCC-methanol synthesis plant). 


\subsection{MILESTONES \& PLANS}

\subsection{Plans for Next Reporting Period}

Efforts for the team during the next reporting period are expected to continue primarily in completing the analysis of the six CEP case studies, refining the capital cost and performance data within the financial model to better predict the most efficient and cost effective commercial coproduction facility.

It is anticipated that preliminary investigation by the vendor will conclude to validate the feasibility of the most promising synthesis gas treatment sorbent, the promoted carbon. It is further anticipated that the results of the preliminary testing could prove out or require modifications to the order of magnitude estimate that has been provided for a sorbent system to solve integration issues between the gasification and methanol plants.

Finally it is anticipated in the upcoming reporting period that the Defense Contractor Audit Agency will provide results and conclusions drawn from the previously executed accounting audit of Global Energy Inc., covering data accumulated over the first year of the IMPPCCT project under the Cooperative Agreement.

\subsection{Project Schedule and Milestones}

Figure 7.2.1 illustrates the Phase I project milestone map. Note the blocks shown in full shading are those associated with the critical path to completion of Phase I. Hollow blocks are tasks which support the overall time table and/or result in deliverable items to DOE. Table 7.2.1 lists the specific deliverable requirements of Phase I.

During the reporting period, the project achieved significant progress for the milestones related to Phase I study of the CEP investigation activities 1.4.3 and 1.8.3. The remaining marketing milestones associated with Ideal and specific CEP case studies are with only minor exception complete. Most of the continuing efforts dedicated to Phase I of this study will be devoted to CEP analysis and generation of outstanding deliverable items to DOE. 
Figure 7.2.1: IMPPCCT Phase I Milestones

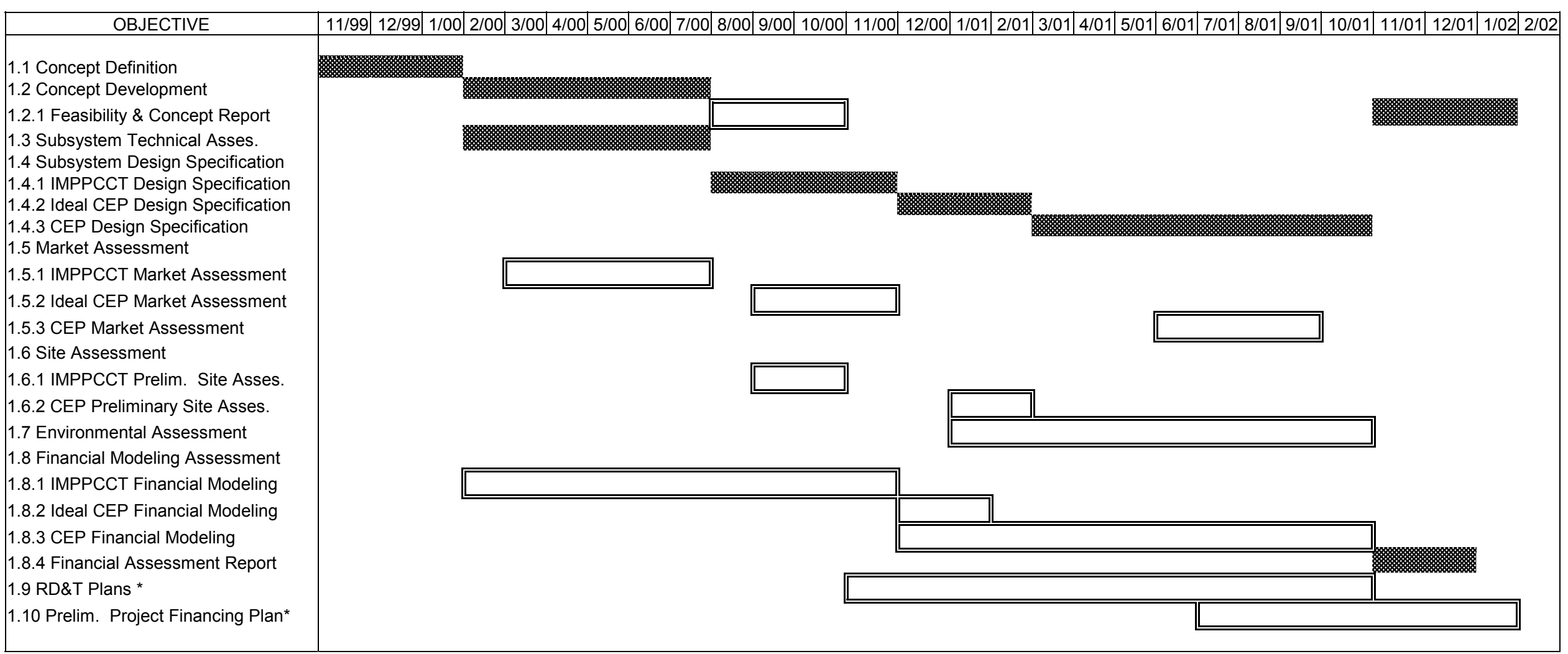

(Shaded blocks indicate critical path)

*Deliverable 


\section{Table 7.2.1: Phase I Deliverable Requirements by Task}

\section{Deliverable Report}

Project Management Plan

Initial Feasibility Report

Concept Report

Site Analysis Report

Economic Analysis

Research, Development and Test Plan

Preliminary Project Financing Plan

\section{Due Date}

60 days after executing a cooperative agreement with DOE, ending Task 1.1

60 days after completing Task 1.2

60 days prior to the end of Phase I, including items from Task 1.2 through Task 1.8 of Phase I

60 days after completing Task 1.6

60 days after completing Task 1.8

60 days prior to the end of Phase I

60 days prior to the end of Phase I

\subsection{Project Cost - Plan and Actual Expenditure}

As shown in Figure 7.3.1, actual expenditure for the reporting period was $\$ 52,902$, with cumulative actual expenditure for the project to be $\$ 661,354$. The numbers include funding from DOE, which is at $80 \%$ of the total, and cost share provided by the consortium members. The data is a reflection of actual invoice totals to the DOE and is current for the period of report issue. Total budget for the project is $\$ 1,933,628$, with DOE providing $\$ 1,546,902$.

It should be noted that some of the industrial consortium participants have not invoiced for work performed in both calendar quarters $4 Q 00$ and 1Q01, hence the actual costs reflected in both presentations are expected to be slightly higher. Nevertheless, the project is substantially under the original budget plan. 
Figure 7.3.1 - Total Phase I Project Spending

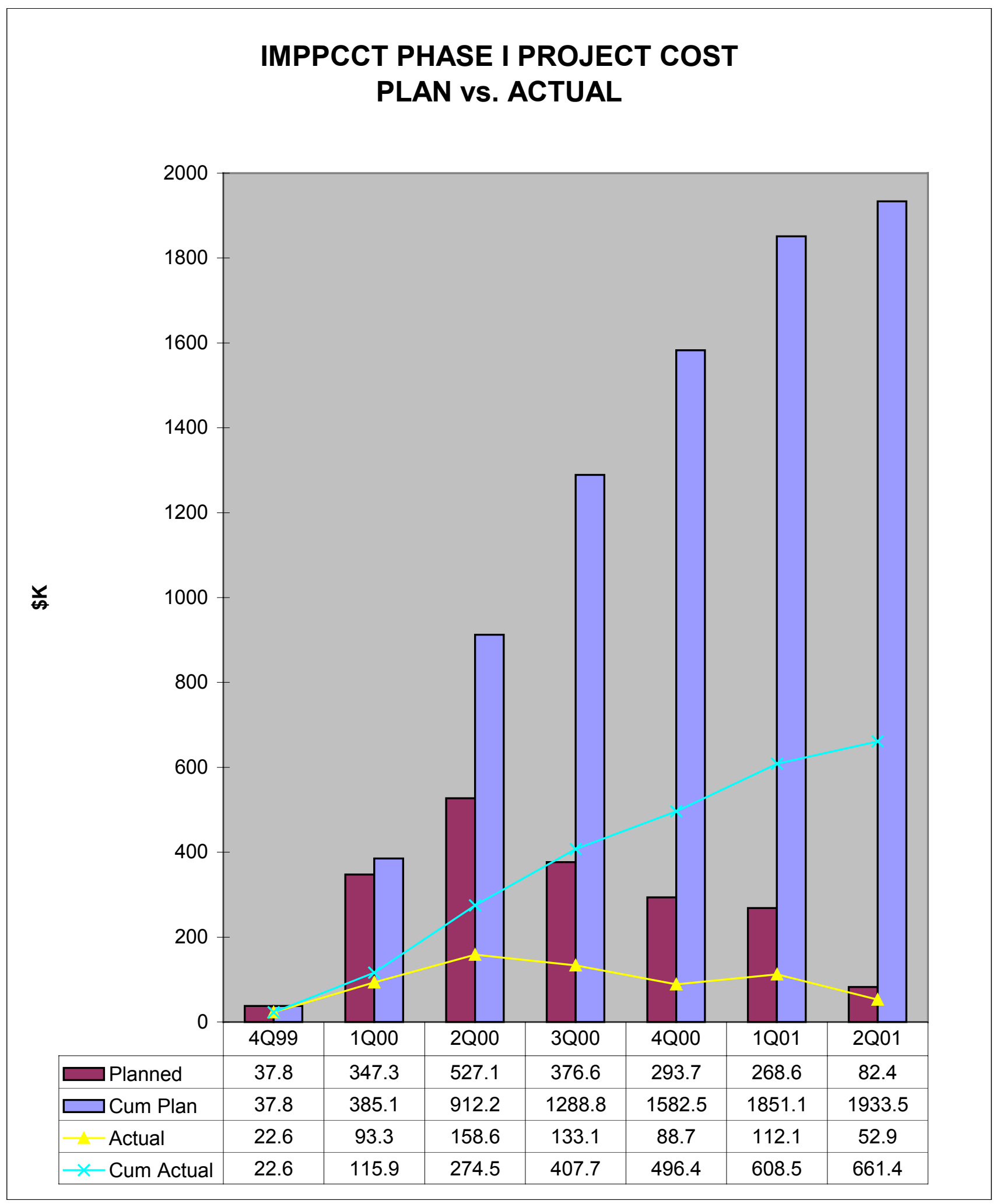




\subsection{REFERENCES}

\subsection{Selected References Available via the Internet}

1. "National Energy Policy", issued by the White House in May 2001. The Wabash River facility and Global Energy received mention in a dedicated sidebar on page 3-6.

http://www.whitehouse.gov/energy/Chapter3.pdf

2. "Wabash River Coal Gasification Repowering Project, An Update", Department of Energy Topical Report No. 20, September 2000, summarizes the history of the Wabash River facility and its construction and four year demonstration under the DOE's Clean Coal Technology program. http://www.lanl.gov/projects/cctc/topicalreports/documents/topical20.pdf

3. "Wabash River Coal Gasification Repowering Project Final Technical Report”, August 2000, 358 pages. This is a very detailed look at the Wabash River facility and its operation 1995-1999. http://www.lanl.gov/projects/cctc/resources/pdfs/wabsh/Final\%20 Report.pdf

4. "Gasification Plant Performance and Cost Optimization", May 2002, (23 MB). The final report of Task 1 of this comprehensive (\$2.4 million) study performed by Global Energy, Nexant and Bechtel under subcontract to the DOE to identify cost savings in the next generation of integrated gasification and coproduction facilities utilizing the E-Gas Technology. Detailed cost estimating by Bechtel. http://www.netl.doe.gov/coalpower/gasification/projects/systems/docs/40342R01.PDF

5. "Wabash River Coal Gasification Repowering Project, A DOE Assessment", January 2002. This is the DOE's official post-project assessment of the Wabash River project. http://www.lanl.gov/projects/cctc/resources/pdfs/wabsh/netl1164.pdf

6. "Environmental Benefits of Clean Coal Technologies" Department of Energy Topical Report No. 18, April 2001. This report describes a variety of processes that are capable of meeting existing and emerging environmental regulations and competing economically in a deregulated electric power marketplace http://www.lanl.gov/projects/cctc/topicalreports/documents/topical18.pdf

7. "Coproduction of Power, Fuel, and Chemicals" Department of Energy Topical Report No. 21, September 2001. A description of the production of synthesis gas (syngas) from coal, the production of electricity from combusting a portion of the syngas and conversion of the remaining syngas to highvalue fuels and chemicals. http://www.lanl.gov/projects/cctc/topicalreports/documents/topical21.pdf

8. The Gasification Technology Council maintains a website (www.gasification.org) that includes a library of the papers presented at recent conferences. Papers presented by Global Energy in 2002 \& 2001:

"Wabash River Repowering IGCC Operations and Performance Update Report", October 2002 http://www.gasification.org/Presentations/2002 papers/GTC02010.pdf

"Comparative IGCC Cost \& performance for Domestic Coals", October 2002

http://www.gasification.org/Presentations/2002 papers/GTC02018.pdf

"NOx Control in IGCC Combustion Turbines: Steam vs. Nitrogen", October 2002 http://www.gasification.org/Presentations/2002 papers/GTC02022.pdf

"Optimized Petroleum Coke IGCC Coproduction Plant", October 2001 http://www.gasification.org/98GTC/GTC01018.pdf

"Environmental Performance of IGCC Repowering for Conventional Coal Power Plants", October 2001 
http://www.gasification.org/98GTC/GTC01037.pdf

\subsection{Other Selected References}

[1] "Wholesale Power Price Projection," Energy Ventures Analysis, Inc, 1901 N. Moore St., Suite 1200, Arlington, VA 22209, June 2001. 